\title{
Effect of endoplasmic reticulum stress on metabolic and stress signaling and kidney-specific functions in Madin-Darby bovine kidney cells
}

\author{
E. Chiappisi, ${ }^{1}$ R. Ringseis, ${ }^{1}$ K. Eder, and D. K. Gessner ${ }^{2}$ \\ Institute of Animal Nutrition and Nutrition Physiology, Justus-Liebig-University Giessen, Heinrich-Buff-Ring 26-32, 35392 Giessen, Germany
}

\begin{abstract}
Recent studies demonstrated induction of endoplasmic reticulum (ER) stress in tissues of cows after parturition, but knowledge about the effect of ER stress on important cellular processes, such as critical signaling and metabolic pathways, in cattle is scarce. Thus, the present study aimed to investigate the effect of ER stress induction on nuclear factor- $\kappa \mathrm{B}(\mathrm{NF}-\kappa \mathrm{B})$, nuclear factor E2-related factor 2 (Nrf2), and sterol regulatory element-binding protein (SREBF1) pathway in MadinDarby bovine kidney (MDBK) cells, a widely used in vitro model in ruminant research. To consider the kidney origin of MDBK cells, the effect on renal distal tubular cell-specific functions, such as transport processes and regulation of $1,25(\mathrm{OH})_{2} \mathrm{D}_{3}$ levels, was also studied. Treatment of MDBK cells with 2 different ER stress inducers, thapsigargin (TG) and tunicamycin (TM), strongly induced ER stress as evident from induction of ER stress target genes, increased phosphorylation of PKR-like ER kinase, and enhanced splicing of Xbox binding protein 1 . The TM decreased the protein concentration of NF- $\mathrm{KB}$ p50 and the mRNA levels of the NF- $\kappa \mathrm{B}$ target genes. Likewise, TG decreased the mRNA concentration of tumor necrosis factor and tended to decrease NF- $\kappa \mathrm{B}$ p50 protein and mRNA levels of NF- $\kappa \mathrm{B}$ target genes. The mRNA levels of most of the Nrf2 target genes investigated were reduced by TG and TM in MDBK cells. Both ER stress inducers reduced the mRNA levels of SREBF1 and its target genes in MDBK cells. Interestingly, TG decreased, but TM increased the mRNA level of the $\mathrm{Ca}^{2+}$ binding protein calbindin 1, whereas the mRNA level of the plasma membrane $\mathrm{Ca}^{2+}$-transporting ATPase 1 remained unchained. The mRNA level of the cytochrome $\mathrm{P} 450$ component 24A1 involved in $1 \alpha$-hydroxylation of $25(\mathrm{OH}) \mathrm{D}_{3}$ was strongly elevated, whereas the mRNA
\end{abstract}

Received December 6, 2016.

Accepted April 28, 2017.

${ }^{1}$ These authors contributed equally to this work.

${ }^{2}$ Corresponding author: denise.gessner@ernaehrung.uni-giessen.de level of the cytochrome P450 component 27A1 catalyzing the breakdown of $1,25(\mathrm{OH})_{2} \mathrm{D}_{3}$ was markedly reduced by both ER stress inducers. The concentration of $1,25(\mathrm{OH})_{2} \mathrm{D}_{3}$ in the supernatant of MDBK cells was increased by approximately $15 \%$ by both TG and TM. The present study indicates that under conditions of ER stress, critical signaling pathways, such as NF- $\kappa B$, Nrf2, and SREBF1, are inhibited, whereas the formation of $1,25(\mathrm{OH})_{2} \mathrm{D}_{3}$ is stimulated in bovine MDBK cells. Future studies are necessary to clarify the physiological relevance of these findings.

Key words: Madin-Darby bovine kidney cell, endoplasmic reticulum stress, inflammation, vitamin D

\section{INTRODUCTION}

Recent studies in dairy cattle have demonstrated activation of a highly conserved stress response pathway, called the unfolded protein response (UPR), in tissues of cows after parturition (Invernizzi et al., 2012; Gessner et al., 2014). The UPR is initiated as a consequence of endoplasmic reticulum (ER) stress, a condition caused by the accumulation of unfolded or misfolded proteins within the ER lumen (Cnop et al., 2012). Endoplasmic reticulum stress itself is induced by different stressors, such as fatty acids, pro-inflammatory cytokines, reactive oxygen species (ROS), and microbial components, such as LPS (Cnop et al., 2012), all of which are frequently elevated in the systemic circulation of dairy cows postpartum (Bradford et al., 2015). Upon sensing of ER stress-inducing stimuli in the ER lumen by the 3 ER stress transducers PKR-like ER kinase (PERK), inositol-requiring enzyme 1 (IRE1), and activating transcription factor 6, a large number of ER stressresponsive genes such as chaperones and components of the ER-associated degradation machinery are induced. This aims to restore ER homeostasis through facilitating protein folding and attenuating accumulation of unfolded and misfolded proteins (Marciniak and Ron, 2006; Ron and Walter, 2007; Cnop et al., 2012). Although UPR has evolved as a homeostatic mechanism preserving ER function, chronic activation of the UPR was found to be related to several diseases in humans, 
such as obesity and diabetes, which have a chronic inflammatory component (Pagliassotti et al., 2016). Endoplasmic reticulum stress is indeed linked with inflammation, because activation of PERK and IRE1 leads to activation of the key regulator of inflammation nuclear factor-kappa B (NF- $\mathbf{\kappa B})$, thereby increasing proinflammatory gene transcription (Cláudio et al., 2013). In addition, ER stress has been demonstrated to stimulate sterol regulatory element-binding protein 1 (SREBF1), the master regulator of lipogenesis, to provide membrane lipids for expansion of the ER (Pagliassotti, 2012).

Despite reporting the occurrence of ER stress in tissues of postpartum dairy cows (Invernizzi et al., 2012; Gessner et al., 2014), little is known with regard to the biological consequences of ER stress in cattle. Recently, it was shown at least in vitro that ER stress induced by fatty acids in cattle cumulus-oocyte complexes during in vitro-maturation impairs oocyte mitochondrial function and compromises oocyte developmental competence (Sutton-McDowall et al., 2016). This might explain at least partially reduced oocyte quality and poor fertility of high-performance dairy cows during peak lactation. Apart from this, knowledge about the modulation of important cellular processes, such as critical signaling and metabolic pathways, by ER stress in cattle is scarce. In view of this, the aim of the present study was to investigate the effect of ER stress induction on critical signaling pathways, such as $\mathrm{NF}-\kappa \mathrm{B}$ and nuclear factor E2-related factor 2 (Nrf2), and metabolic pathways, such as SREBF1, all of which are known to be affected by ER stress in other cell models and to be altered under specific pathophysiological conditions, in a bovine cell line. As a bovine cell line, Madin-Darby bovine kidney (MDBK) cells representing an immortalized kidney tubule cell line (Glendenning et al., 2000) were used for this study. Although the kidney is usually not in the focus of research with periparturient dairy cattle, MDBK cells are an established in vitro model in ruminant research due to the lack of cell lines from other bovine tissues (Bionaz et al., 2008; Thering et al., 2009). In addition, MDBK cells are a suitable cell model for ER stress because it is known that ER stress can be induced in MDBK cells by various ER stress-inducing agents (Jordan et al., 2002). Although the use of primary cells isolated from bovine tissues could also come into question for this study in principle, the main disadvantage of primary cells compared with cell lines is that they are more difficult to maintain and manipulate in culture and the results obtained are less reproducible. To consider the kidney origin of MDBK cells, we also studied the effect of ER stress on renal distal tubular cell-specific functions, such as tubular transport processes and the regu- lation of plasma levels of $1,25(\mathrm{OH})_{2} \mathrm{D}_{3}$ (calcitriol), the biologically most active form of vitamin $\mathrm{D}$. To induce ER stress in MDBK cells, 2 different ER stress inducers, tunicamycin (TM) and thapsigargin (TG), were used, which are widely described in the literature and exert ER stress via different mechanisms; TM inhibits protein glycosylation (de Virgilio et al., 1999) and TG inhibits the sarco-/endoplasmic reticulum calcium ATPase (SERCA; Mengesdorf et al., 2001).

\section{MATERIALS AND METHODS}

\section{Cell Culture and Treatments}

For this investigation, we used MDBK cells, which were obtained from Cell Lines Service (Eppelheim, Germany). The culture medium consisted of HyClone minimum essential medium/Earle's balanced salt solution supplemented with $10 \%$ fetal bovine serum and $0.05 \mathrm{mg} / \mathrm{mL}$ of gentamicin (Invitrogen, Karlsruhe, Germany). The MDBK cells were maintained at $37^{\circ} \mathrm{C}$ in a humidified $5 \% \mathrm{CO}_{2}$ in air atmosphere. For experiments, MDBK cells were seeded out into 96-well plates at a density of $1.3 \times 10^{4}$ cells per well (for cell viability assay), 24-well plates at a density of $7.0 \times 10^{4}$ cells per well [for quantitative real-time PCR (qPCR) and ELISA experiments], and 6-well plates at a density of $2.0 \times 10^{5}$ cells per well (for immunoblot experiments) in HyClone minimum essential medium/Earle's balanced salt solution complete medium. After reaching $70 \%$ confluency, cells were incubated for $24 \mathrm{~h}$ with culture medium supplemented with different concentrations of $\mathrm{TM}(0.01,0.05,0.1,0.5,1$, and $5 \mu \mathrm{g} / \mathrm{mL})$ or $\mathrm{TG}(0.01$, $0.05,0.1,0.5,1$, and $5 \mu \mathrm{mol} / \mathrm{L})$ dissolved in dimethyl sulfoxide (DMSO; Sigma-Aldrich, Steinheim, Germany). As vehicle controls (indicated as 0 ), culture medium was supplemented with $0.1 \%$ DMSO or $0.5 \%$ DMSO for TM or TG, respectively. Preliminary cell viability assays revealed no effect of DMSO at concentrations of 0.1 and $0.5 \%$ compared with cells treated without DMSO. All experiments were performed 3 times from a different cell passage number (3 independent experiments). An independent experiment was defined as an experiment performed with cells of a specific passage number and included seeding, treatment, and analysis.

\section{Cell Viability Assay}

For the assessment of cell toxic effects of TM and TG, cell viability based on mitochondrial function was assayed by measuring the ability of cells to convert soluble 3-(4,5-dimethylthiazol-2-yl)-2,5-diphenyltetrazolium bromide (MTT; Sigma-Aldrich) into an insoluble purple formazan reaction product. Following treatment 
of cells with different concentrations of TM and TG as indicated, incubation medium was replaced with 100 $\mu \mathrm{L}$ of MTT solution $(1 \mathrm{mg} / \mathrm{mL}$ in PBS, sterilized by filtration) and cells were incubated for $4 \mathrm{~h}$. The MTT solution was then aspirated and formazan was dissolved by addition of $200-\mu \mathrm{L}$ sterile-filtered acidified isopropanol and gentle stirring on a plate shaker for $15 \mathrm{~min}$. The absorbance was measured at $450 \mathrm{~nm}$ using a microplate reader (Infinite M200, Tecan, Männedorf, Switzerland). In each independent experiment, 7 concentrations of either TM $(0,0.01,0.05,0.1,0.5,1$, and $5 \mu \mathrm{g} / \mathrm{mL})$ or TG $(0,0.01,0.05,0.1,0.5,1$, and $5 \mu \mathrm{mol} / \mathrm{L})$ were represented in 9 wells ( 9 technical replicates per treatment) per 96-well plate. One 96-well plate was used each for TM and TG. Within one independent experiment, all 9 technical replicates were analyzed and a single mean representing the experimental unit was calculated for each treatment. Mean absorbance value of vehicle control was set to $100 \%$, and the means and standard deviations of absorbance values of TM- and TG-treated cells, respectively, was presented relative to that of the vehicle control. Three independent experiments were run. Thus, the total number of experimental units was 3.

\section{RNA Isolation and qPCR}

Following treatment of cells with different concentrations of TM and TG as indicated, cell medium was discarded and the cell layer was washed once with PBS and plates were immediately stored at $-80^{\circ} \mathrm{C}$ until RNA isolation. Total RNA was isolated using TRIzol reagent (Invitrogen, Karlsruhe, Germany) according to the manufacturer's protocol. Concentration and purity of the total RNA were estimated from the optical density at 260 and $280 \mathrm{~nm}$, respectively (NanoQuant Plate and Infinite M200 microplate reader, Tecan). The average optical density A260/A280 ratio of all samples was $1.84 \pm 0.03$ (mean $\pm \mathrm{SD})$. The $\mathrm{cDNA}$ was generated by reverse transcription of $1.2 \mu \mathrm{g}$ of total RNA as described recently in detail (Gessner et al., 2016). The relative mRNA expression of genes was measured with a Rotor-Gene Q system (Qiagen, Hilden, Germany) using KAPA SYBR FAST qPCR Mastermix (Peqlab, Erlangen, Germany) and gene-specific primer pairs (Eurofins MWG Operon, Ebersberg, Germany). Gene-specific primer pairs were designed using Primer3 (Rozen and Skaletsky, 2000) and Basic Local Alignment Search Tool (Altschul et al., 1990). Characteristics of primers used for qPCR analysis are shown in Table 1. Most primer pairs were designed to span an exon-exon junction. All reactions were performed using the following thermal cycler conditions: $95^{\circ} \mathrm{C}$ for $3 \mathrm{~min}$, followed by 35 to 40 cycles of a 3 -step reaction: denaturation at $95^{\circ} \mathrm{C}$ for $3 \mathrm{~s}$, annealing at $60^{\circ} \mathrm{C}$ for $20 \mathrm{~s}$, and extension at $72^{\circ} \mathrm{C}$ for $1 \mathrm{~s}$. The reaction was followed by a melting curve from 50 to $95^{\circ} \mathrm{C}$ in 5 -s increments of $1^{\circ} \mathrm{C}$ to ensure amplification specificity. The amplified PCR products were separated electrophoretically using a 1.5\% agarose gel stained with GelRed nucleic acid gel stain (Biotium, Hayward, CA) to confirm the amplification of a single PCR product of the expected size. All amplicons were sequenced to confirm the specificity of primers (LGC Genomics, Berlin, Germany). Sequences were deduced from data obtained for both strands and compared with the corresponding GenBank sequence from the National Center for Biotechnology Information (Table 1) using the SeqMan II program (DNASTAR Inc., Madison, WI). The sequence analysis showed $99.94 \%$ sequence identity for all sequenced amplicons. For calculation of mRNA levels, cycle threshold $(\mathbf{C t})$ values of reference and target genes were obtained using Rotor-Gene Q Software (Qiagen). Raw Ct-values of reference genes were transformed into relative expression values using the $2^{-\Delta \mathrm{Ct}}$ equation for the calculation of normalization factors. The $2^{-\Delta \mathrm{Ct}}$ equation was used considering that the amplification efficiency of all primer pairs was close to 2 , except for $I L 1 B$ (Table 1). The amplification efficiencies were determined using serial dilutions prepared from pooled MDBK cDNA with sterile water and calculated from the slope of the regression line. The highest relative value of each gene was set to 1 . From these values, the normalization factor was calculated as the geometric mean of expression data of the 3 most stable [TM: peptidylprolyl isomerase A (PPIA), ribosomal protein L12 (RPL12), ribosomal protein S9 (RPS9); TG: ATP synthase, $\mathrm{H}^{+}$transporting, mitochondrial F1 complex, $\beta$ polypeptide (ATP5B), RPL12, and RPS9] out of several potential reference genes evaluated in previous studies with MDBK cells (Zhou et al., 2015) according to the method of Vandesompele et al. (2002). The Ct-values of target genes were also transformed into relative expression values using the $2^{-\Delta \mathrm{Ct}}$ equation and were normalized with the individual normalization factor resulting in relative gene quantities that were used for statistical analysis. In each independent experiment, 3 concentrations of either TM $(0,0.1$, and $1.0 \mu \mathrm{g} / \mathrm{mL})$ or TG $(0,0.1$, and $1.0 \mu \mathrm{mol} / \mathrm{L})$ were represented in 8 wells per 24-well plate. One 24-well plate was used for TM and one for TG. During RNA extraction, the RNA from 2 wells of the same treatment was pooled. Thus, 4 RNA pools (4 technical replicates) per treatment were used for qPCR analysis. Within 1 independent experiment, all technical replicates were analyzed and a single mean representing the experimental unit was calculated for each treatment. The mean of vehicle control (concentration of 0 ) was set to 1.0 , and the mean and standard deviation of the other 
Table 1. Characteristics of gene-specific primers used for quantitative real-time PCR

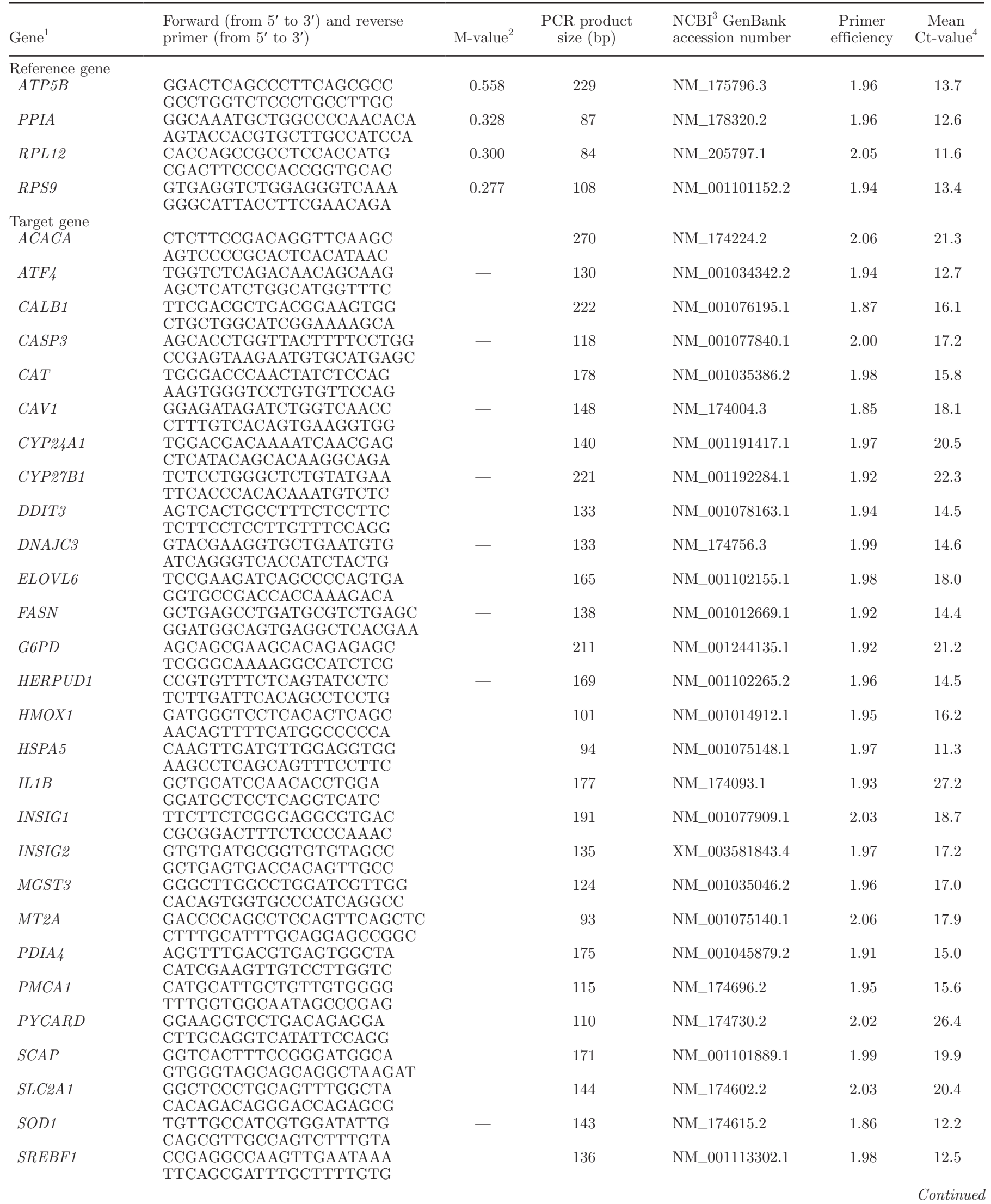


Table 1 (Continued). Characteristics of gene-specific primers used for quantitative real-time PCR

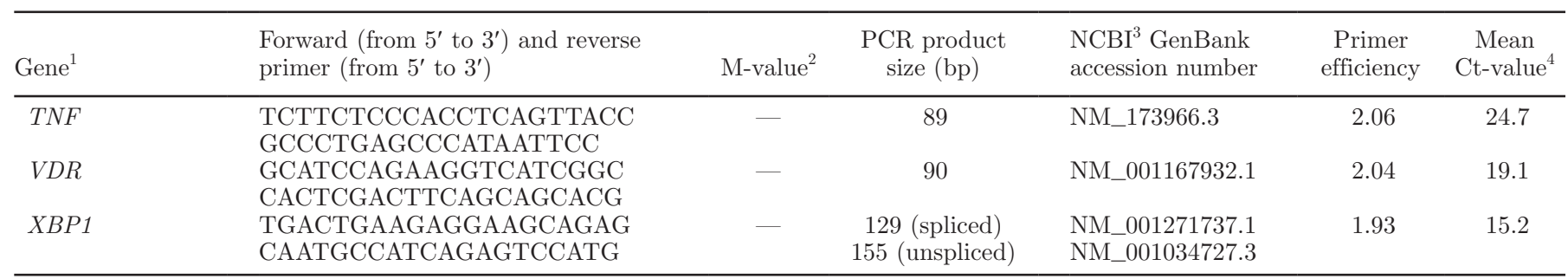

${ }^{1} A C A C A=$ acetyl-CoA carboxylase $\alpha ; A T F 4=$ activating transcription factor $4 ; A T P 5 B=\mathrm{ATP}$ synthase, $\mathrm{H}^{+}$transporting, mitochondrial F1 complex, $\beta$ polypeptide; $C A L B 1=$ calbindin; $C A S P 3=$ caspase $3 ; C A T=$ catalase; $C A V 1=$ caveolin; $C Y P 24 A 1=$ cytochrome P450 family 24 subfamily A member $1 ; C Y P 27 B 1=$ cytochrome P450 family 27 subfamily B member $1 ; D D I T 3=$ DNA damage inducible transcript 3; DNAJC3 = DnaJ heat shock protein family (Hsp40) member C3; ELOVL6 = fatty acid elongase 6; FASN = fatty acid synthase; G6PD = glucose-6-phosphate dehydrogenase; HERPUD1 = homocysteine inducible ER protein with ubiquitin like domain $1 ; H M O X 1=$ heme oxygenase 1; HSPA $5=$ heat shock protein family A (Hsp70) member 5 ; IL1B = interleukin $1 \beta ;$ INSIG $=$ insulin induced gene; MGST3 = microsomal glutathione S-transferase 3;MT2A = metallothionein $2 \mathrm{~A} ; P D I A 4=$ protein disulfide isomerase family A member $4 ; P M C A 1=$ ATPase plasma membrane $\mathrm{Ca}^{2+}$ transporting $1 ; P P I A=$ peptidylprolyl isomerase A; PYCARD = PYD and CARD domain containing; $R P L 12=$ ribosomal protein L12; RPS9 = ribosomal protein S9; SCAP = SREBF chaperone; SLC2A1 = solute carrier family 2 member $1 ; S O D 1=$ superoxide dismutase

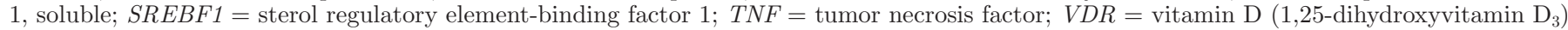
receptor; $X P B 1=\mathrm{X}$-box binding protein 1 .

${ }^{2} \mathrm{M}$-value $=$ average expression stability value.

${ }^{3} \mathrm{NCBI}=$ National Center for Biotechnology Information.

${ }^{4} \mathrm{Ct}=$ cycle threshold.

concentrations were scaled proportionally to show the changes in mRNA expression as fold of vehicle control. Three independent experiments were run. Thus, the total number of experimental units was 3 .

\section{Immunoblotting}

Following treatment of cells with different concentrations of TM and TG as indicated, medium was discarded and cells were washed with PBS and harvested using a cell scraper (Sarstedt, Nümbrecht, Germany). The cells were centrifuged for 5 min at $350 \times g$ and $4^{\circ} \mathrm{C}$. The resulting cell pellet was dissolved with $30 \mu \mathrm{L}$ of RIPA buffer [50 mM Tris, $150 \mathrm{~m} \mathrm{M} \mathrm{NaCl,} 10 \%$ glycerol, $0.1 \%$ SDS, $1 \%$ Triton X-100, $1 \mathrm{~m} M$ EDTA, 0.5\% deoxycholate, $1 \%$ protease inhibitor cocktail (Sigma-Aldrich), 1\% phosphatase inhibitor cocktail (PhosSTOP, SigmaAldrich); $\mathrm{pH}$ 7.5], and incubated on ice on ice for 30 min with vortexing for $10 \mathrm{~min}$. The samples were then centrifuged at $12,000 \times g$ for $15 \mathrm{~min}$ and $4^{\circ} \mathrm{C}$ and supernatant/cell lysate was collected for the determination of PERK and $\beta$-actin protein expression. Nuclear extracts for determination of $\mathrm{NF}-\kappa \mathrm{B} / \mathrm{p} 50$ were prepared using a Nuclear Extract Kit (Active Motif, Rixensart, Belgium) according to the manufacturer's protocol. Protein concentrations of cell lysates and nuclear extracts were determined by the bicinchoninic acid protein assay kit (Interchim, Montluçon, France) with BSA as standard. Fifteen micrograms of protein were separated by $10 \%$ SDS-PAGE and electro-transferred to nitrocellulose membrane (Pall Corporation, Pensacola, FL). Revers- ible Ponceau S (Carl Roth, Karlsruhe, Germany) staining was performed to check equal protein transfer to the membranes. After that, the membranes were washed and blocked for $1 \mathrm{~h}$ at room temperature with $5 \%$ nonfat dry milk (wt/vol) in Tris-buffered saline with $0.1 \%$ Tween 20 following overnight incubations with primary antibodies against $\mathrm{NF}-\kappa \mathrm{B} / \mathrm{p} 50$ (rabbit polyclonal antiNF-кB/p50 antibody H-119; Santa Cruz Biotechnology, Heidelberg, Germany), total PERK (goat polyclonal anti-PERK antibody T-19; Santa Cruz Biotechnology), phospho-PERK [pPERK; rabbit monoclonal antipPERK(Th980) antibody; Cell Signaling Technology, Danvers, MA], and $\beta$-actin (mouse monoclonal anti- $\beta$ actin antibody ab6276, Cambridge, UK) at $4^{\circ} \mathrm{C}$ as a reference protein for adequate normalization. Subsequently, the membranes were washed and incubated at room temperature with a horseradish peroxidase-conjugated secondary polyclonal anti-rabbit-IgG antibody (A0545, Sigma-Aldrich), anti-mouse-IgG antibody (ab6728, Abcam, Cambridge, UK), or anti-goat-IgG antibody (sc2020, Santa Cruz Biotechnology) for $1.5 \mathrm{~h}$. The HRP activity was detected using chemiluminescent reagents (Amersham ECL Select Western Blotting Detection Reagent, GE Healthcare, Freiburg, Germany). The signal intensities of specific bands were detected with a Bio-Imaging system (Syngene, Cambridge, UK) and quantified using Syngene GeneTools software. For calculation of protein levels, the band intensity of the proteins of interest was normalized by that of $\beta$-actin. In each independent experiment, 3 concentrations of either $\operatorname{TM}(0,0.1$, and $1.0 \mu \mathrm{g} / \mathrm{mL})$ or TG $(0,0.1$, and 1.0 
$\mu \mathrm{mol} / \mathrm{L})$ were represented in 2 wells per 6 -well plate. Two identical 6-well plates were used each for TM and TG. Thus, the number of technical replicates was 4 . Within one independent experiment, all 4 technical replicates per treatment were analyzed and a single mean representing the experimental unit was calculated for each treatment. The mean of vehicle control (concentration of 0 ) was set to 1.0, and the mean and standard deviation of the other concentrations were scaled proportionally to show the changes in protein expression as fold of vehicle control. Three independent experiments were run. Thus, the total number of experimental units was 3 .

\section{Determination of $1,25(\mathrm{OH})_{2} \mathrm{D}_{3}$ Concentration in the Supernatant of MDBK Cells}

Following treatment of cells with different concentrations of TM and TG as indicated, cell medium was collected at the end of incubation and centrifuged at $200 \times g$ for $10 \mathrm{~min}$ at $4^{\circ} \mathrm{C}$ and the supernatant was stored at $-80^{\circ} \mathrm{C}$ pending analysis. Concentration of $1,25(\mathrm{OH})_{2} \mathrm{D}_{3}$ in the supernatant of MDBK cells after treatment with different concentrations of TM and TG was determined by the bovine ELISA kit from Cusabio (CSB-EQ027278BO, Wuhan, China).

\section{Statistics}

All data represent means and standard deviation, which were calculated from 3 independent experiments each. The statistical analysis was performed using Minitab Statistical Software (release 13.0, Minitab Inc., State College, PA). Conformity of variables to normal distribution was confirmed with the Anderson-Darling test. Differences between groups were analyzed using the Fisher's multiple range test for parametric variables. Means were considered significant at $P<0.05$.

\section{RESULTS}

\section{ER Stress Inducers Impair Cell Viability of MDBK Cells}

Because sustained ER stress is known to cause cell death via apoptosis, which is known to interfere with other cellular functions, it is critical to study the effect of ER stress inducers on cell viability. Thus, at the beginning of this study, the viability of MDBK cells was evaluated in response to $24 \mathrm{~h}$ treatment with increasing concentrations of TM (from 0.01 to $5 \mu \mathrm{g} / \mathrm{mL}$ ) and TG (from 0.01 to $5 \mu \mathrm{mol} / \mathrm{L}$ ). Treatment with TM for 24 $\mathrm{h}$ decreased MDBK cell viability moderately by $10 \%$ at $0.05 \mu \mathrm{g} / \mathrm{mL}$ and by $24 \%$ at the highest concentra- tion tested $(P<0.05$, Figure $1 \mathrm{~A})$. Treatment with TG for $24 \mathrm{~h}$ impaired viability of MDBK cells by $12 \%$ at the lowest concentration tested and by about $28 \%$ at $0.05 \mu \mathrm{mol} / \mathrm{L}(P<0.05$, Figure 1B). At concentrations
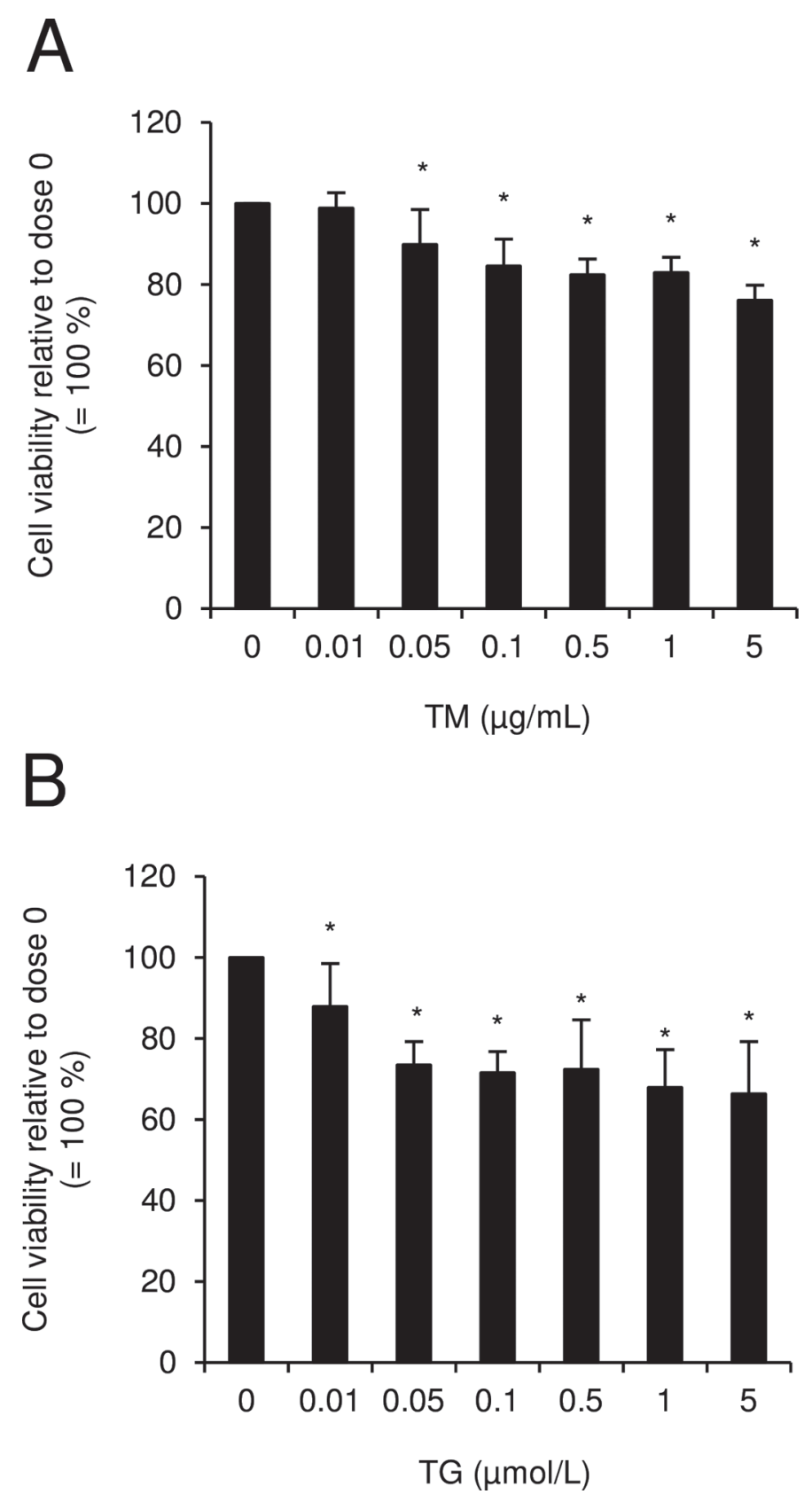

Figure 1. Effect of 24-h treatment with different concentrations of (A) tunicamycin (TM; $0,0.01,0.05,0.1,0.5,1$, and $5 \mu \mathrm{g} / \mathrm{mL}$ ) or (B) thapsigargin (TG; $0,0.01,0.05,0.1,0.5,1$, and $5 \mu \mathrm{mol} / \mathrm{L}$ ) on viability of Madin-Darby bovine kidney cells. Cells treated with dimethyl sulfoxide $(0.5 \%$ for TM and $0.1 \%$ for TG) as vehicle served as the control $(0 \mu \mathrm{g} / \mathrm{mL}$ of TM, $0 \mu \mathrm{mol} / \mathrm{L}$ of TG). Bars represent cell viability relative to vehicle control $(0 \mu \mathrm{g} / \mathrm{mL}$ of TM, $0 \mu \mathrm{mol} / \mathrm{L}$ of TG), which was set to $100 \%$, and are means \pm SD from 3 independent experiments. $* P<0.05$. 
$>0.05 \mu \mathrm{mol} / \mathrm{L}$, TG further impaired cell viability, but only slightly more, by no more than $34 \%$ at the highest concentration tested compared with control cells $(P<$ 0.05). For the subsequent experiments, the effect of TM and TG was explored at 2 concentrations (TM: 0.1 and $1 \mu \mathrm{g} / \mathrm{mL}$; TG: 0.1 and $1 \mu \mathrm{mol} / \mathrm{L}$ ), at which MDBK cell viability was moderately decreased $(16-18 \%$ by TM and $29-32 \%$ by TG). This enabled us to reduce, but not to completely exclude, bias effects of impaired cell viability on cellular effects caused by ER stress.

\section{ER Stress Inducers Cause Activation of Unfolded Protein Response in MDBK Cells}

To study induction of ER stress, the effect of 24 $\mathrm{h}$ treatment with $\mathrm{TM}(0.1$ and $1 \mu \mathrm{g} / \mathrm{mL})$ and $\mathrm{TG}$ $(0.1$ and $1 \mu \mathrm{mol} / \mathrm{L})$ on relative mRNA levels of several ER stress/UPR target genes was investigated in MDBK cells. The TG and TM increased the mRNA levels of activating transcription factor 4 (ATF4), caspase 3 (CASP3), DNA damage inducible transcript 3 (DDIT3), DnaJ heat shock protein family ( $\left.\mathrm{Hsp}_{4} \mathrm{O}\right)$ member C3 (DNAJC3), homocysteine inducible ER protein with ubiquitin like domain 1 (HERPUD1), heat shock protein family A (Hsp70) member 5 (HSPA5), and protein disulfide isomerase family A member 4 $(P D I A 4)$ at both concentrations tested $(P<0.05)$, and TG and TM caused similar fold increases of mRNA levels at the low and the high concentrations tested (Figures 2A and 2B). The fold increases of ER stress/ UPR target genes ranged from 2.5- to 20.2-fold and from 1.3- to 17.3-fold for MDBK cells treated with TG and TM, respectively. The DDIT3 and HSPA5 were the most strongly induced ER stress/UPR target genes in response to both ER stress inducers. To further confirm that ER stress was induced by both ER stress inducers in MDBK cells, splicing of X-box binding protein 1 $(X B P 1)$ was investigated in response to both TG and TM. As shown in Figures 2C and 2D, a 129-bp PCR product representing the spliced XBP1 mRNA could be clearly detected by agarose gel electrophoresis in MDBK cells treated with TG and TM at both concentrations, but not in control cells. Besides upregulation of UPR target genes and XBP1 splicing, phosphorylation of the ER stress sensor PERK is a key event of ER stress induction. Thus, phosphorylation of PERK was also studied in MDBK cells treated with TG and TM. Figures $2 \mathrm{E}$ and $2 \mathrm{~F}$ shows that the relative protein level of pPERK was strongly elevated in MDBK cells treated with the high concentration of either TG or TM $(P<0.05)$, whereas the protein level of total PERK remained unchanged. Collectively, these results clearly demonstrated that ER stress inducers cause a typical ER stress response in MDBK cells.

\section{ER Stress Inducers Inhibit Expression of Genes Regulated by Inflammatory Signaling Pathways in MDBK Cells}

To next study whether induction of ER stress in MDBK cells influences inflammatory signaling pathways, such as NF- $\mathrm{BB}$ and NOD-like receptor P3 (NLRP3) inflammasome, the effect of TG and TM on the mRNA levels of target genes of $N F-\kappa B$ and NLRP 3 inflammasome [caveolin (CAV1), interleukin $1 \beta$ (IL1B), tumor necrosis factor $(T N F)$, and PYD and CARD domain containing $(P Y C A R D)]$ and the protein levels of $\mathrm{NF}-\kappa \mathrm{B}$ subunit p50 was investigated. Figures $3 \mathrm{~A}$ and $3 \mathrm{C}$ demonstrates that the mRNA levels of $C A V 1, I L 1 B$, $T N F$, and PYCARD and the protein concentration of p50 were reduced by 20 to $50 \%$ in response to TM at both concentrations in MDBK cells $(P<0.05)$. Treatment with the low and the high concentration of TG caused a significant decrease of the mRNA level of TNF by about $40 \%(P<0.05)$, whereas the mRNA levels of $C A V 1, I L 1 B$, and PYCARD and the protein concentration of p50 were only numerically, but not significantly, reduced in response to TG by about 15 to $30 \%$ (Figure $3 \mathrm{~B}$ and $3 \mathrm{D})$.

\section{ER Stress Inducers Inhibit Expression of Cytoprotective Genes Regulated by Nrf2 in MDBK Cells}

To evaluate activation of Nrf2 signaling pathway upon induction of ER stress in MDBK cells, the effect of TG and TM on relative mRNA levels of several cytoprotective genes [catalase $(C A T)$, microsomal glutathione S-transferase 3 (MGST3), heme oxygenase 1 (HMOX1), metallothionein 2A (MT2A), and superoxide dismutase 1 (SOD1)] regulated by Nrf2 was studied. As illustrated in Figure 4A, TM significantly decreased the mRNA levels of MGST3, MT2A, and SOD1 $(P<0.05)$. The TG reduced only the mRNA levels of MGST3 and MT2A at both concentrations tested $(P<0.05$, Figure $4 B)$. Neither TM nor TG altered the mRNA levels of $C A T$ and HMOX1 (data not shown).

\section{ER Stress Inducers Inhibit Expression of Lipogenic Genes Regulated by SREBF1 in MDBK Cells}

Activation of SREBF1 and upregulation of lipogenic genes regulated by SREBF1 during ER stress has been repeatedly reported in different cell systems. To explore whether ER stress inducers regulate lipogenic gene expression in MDBK cells, the mRNA levels of SREBF1, acetyl-CoA carboxylase $\alpha(A C A C A)$, ELOVL fatty acid elongase 6 ( $E L O V L 6)$, fatty acid synthase $(F A S N)$, glucose-6-phosphate dehydrogenase $(G 6 P D)$, and the 
regulators of $S R E B F 1$ processing, insulin induced gene 1 (INSIG1), INSIG2, and SREBF cleavage activating protein $(S C A P)$ were determined in response to TG and TM. Figures 5A and 5B show that TG and TM at both concentrations markedly decreased the mRNA levels of lipogenic genes (ACACA, ELOVL6, FASN, and $G 6 P D$ ) by about 40 to $90 \%$ and the mRNA con- centration of SREBF 1 by 20 to $30 \%$ in MDBK cells ( $P$ $<0.05)$. The mRNA level of SCAP was increased about 2 -fold by both ER stress inducers $(P<0.05$, Figures $5 \mathrm{~A}$ and $5 \mathrm{~B}$ ), whereas the mRNA level of INSIG1 was decreased markedly by TM at both concentrations and slightly by TG at the high concentration $(P<0.05$, Figures $5 \mathrm{~A}$ and $5 \mathrm{~B})$. The mRNA level of INSIG2 was
A
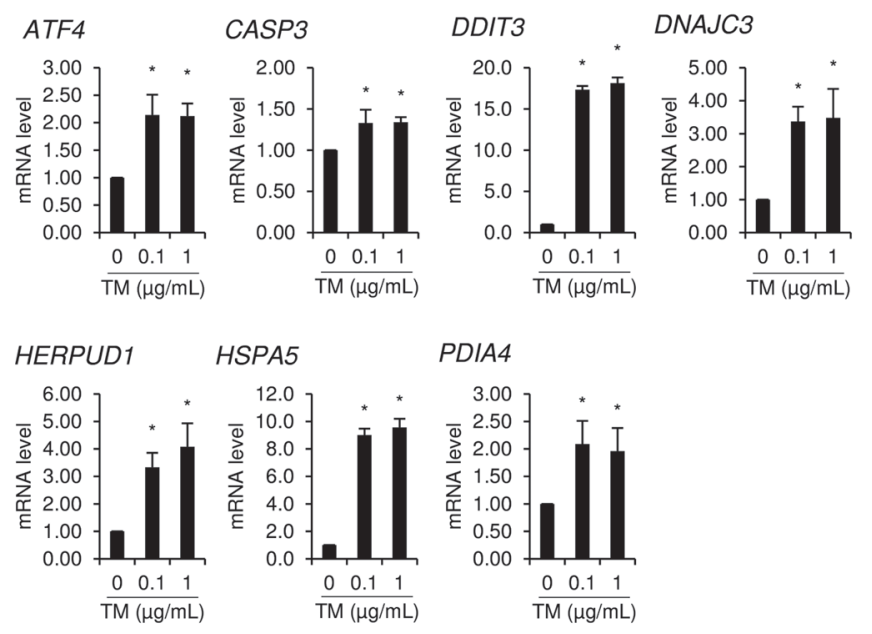

$\mathrm{B}$
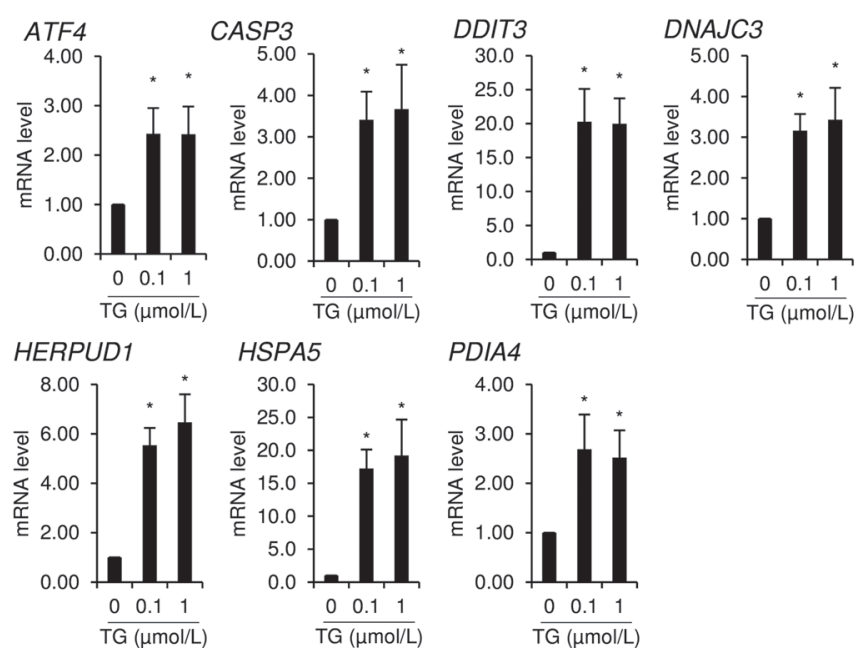

C
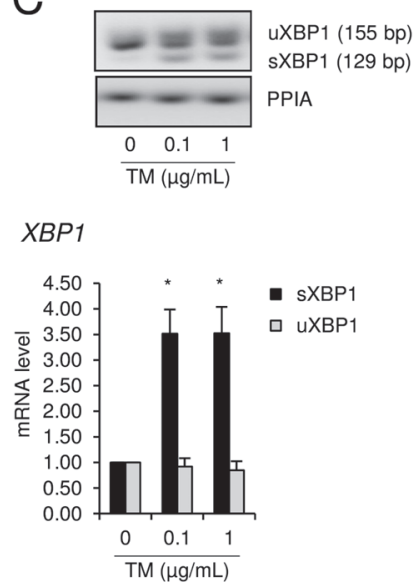

D
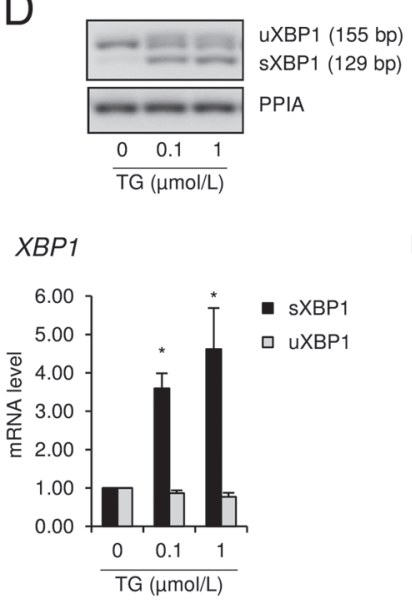

E
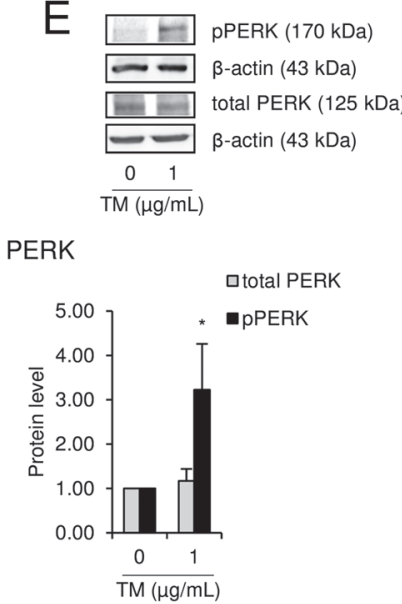

$\mathrm{F}$

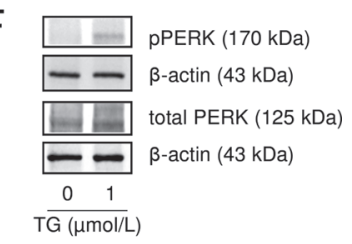

PERK

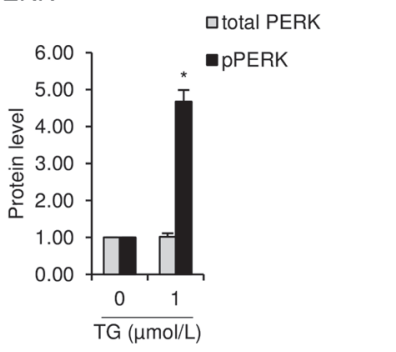

Figure 2. Effect of 24-h treatment with different concentrations of (A) tunicamycin (TM; 0, 0.1, and $1 \mu \mathrm{g} / \mathrm{mL})$ or $(\mathrm{B})$ thapsigargin (TG; $0,0.1$, and $1 \mu \mathrm{mol} / \mathrm{L}$ ) on relative mRNA levels of unfolded protein response target genes activating transcription factor 4 (ATF 4), caspase 3 (CASP3), DNA damage inducible transcript 3 (DDIT3), DnaJ heat shock protein family (Hsp40) member C3 (DNAJC3), homocysteine inducible ER protein with ubiquitin like domain 1 (HERPUD1), heat shock protein family A (Hsp70) member 5 (HSPA5), and protein disulfide isomerase family A member 4 (PDIA4) in Madin-Darby bovine kidney (MDBK) cells. Cells treated with dimethyl sulfoxide (0.5\% for TM and $0.1 \%$ for TG) as vehicle served as the control $(0 \mu \mathrm{g} / \mathrm{mL}$ of $\mathrm{TM}, 0 \mu \mathrm{mol} / \mathrm{L}$ of TG). Bars represent relative mRNA level expressed as fold of the control $(0 \mu \mathrm{g} / \mathrm{mL}$ of TM, $0 \mu \mathrm{mol} / \mathrm{L}$ of TG) and are means $\pm \mathrm{SD}$ from 3 independent experiments. Representative images of XBP1 activation by unconventional splicing in MDBK cells after 24-h treatment with different concentrations of (C) TM $(0,0.1$, and $1 \mu \mathrm{g} / \mathrm{mL})$ or $(\mathrm{D}) \mathrm{TG}(0,0.1$, and $1 \mu \mathrm{mol} / \mathrm{L}$ ) demonstrating the unspliced (u; $155 \mathrm{bp}$ ) and the spliced (s; $129 \mathrm{bp}$ ) XBP1 mRNA as detected by conventional PCR followed by agarose gel electrophoresis. Peptidylprolyl isomerase A (PPIA) was also detected by conventional PCR and served as a loading control for agarose gel electrophoresis. Bars represent results from densitometric analysis of bands for uXBP1 and sXBP1 mRNA and are expressed as fold of the control $(0 \mu \mathrm{g} / \mathrm{mL}$ of TM, $0 \mu \mathrm{mol} / \mathrm{L}$ of TG) and are means $\pm \mathrm{SD}$ from 3 independent experiments. Representative gel blots depicting protein level of phosphorylated PKR-like ER kinase (pPERK) and total PERK in MDBK cells after 24-h treatment with (E) $1 \mu \mathrm{g} / \mathrm{mL}$ of TM or $(\mathrm{F}) 1 \mu \mathrm{mol} / \mathrm{L}$ of TG. Abundance of $\beta$-actin protein served as a loading control. Bars represent relative protein level expressed as fold of the control $\left(0 \mu \mathrm{g} / \mathrm{mL}\right.$ of TM, $0 \mu \mathrm{mol} / \mathrm{L}$ of TG) and are means $\pm \mathrm{SD}$ from 3 independent experiments. ${ }^{*} P<0.05$. 
strongly elevated by TG at both concentrations $(P<$ 0.05 ), whereas TM had no effect (Figures $5 \mathrm{~A}$ and $5 \mathrm{~B}$ ).

\section{ER Stress Inducers Modulate the Expression of Transporters Involved in Renal Tubular $\mathrm{Ca}^{2+}$ Transport and Glucose Transport in MDBK Cells}

Transcellular $\mathrm{Ca}^{2+}$ transport plays an exclusive role in distal renal tubules. To investigate whether ER stress influences genes involved in transcellular $\mathrm{Ca}^{2+}$ transport in the distal renal tubular cell line MDBK, the mRNA levels of plasma membrane $\mathrm{Ca}^{2+}$-transporting ATPase $1[P M C A 1$, synonymous gene symbol of ATPase plasma membrane $\mathrm{Ca}^{2+}$ transporting 1 (ATP2B1)] and calbindin 1 ( $C A L B 1)$ were determined in MDBK cells treated for $24 \mathrm{~h}$ with TM or TG. Figures $6 \mathrm{~A}$ and $6 \mathrm{~B}$ demonstrate that the mRNA levels of these transporters were differentially regulated by both ER stress inducers. The TM increased the CALB1 mRNA level at both concentrations tested $(P<0.05)$, but decreased $P M C A 1$ mRNA level only at the high concentration $(P<$ 0.05, Figure $6 \mathrm{~A}$ ). In contrast, TG markedly decreased $C A L B 1 \mathrm{mRNA}$ level $(P<0.05)$, but did not change the mRNA level of PMCA1 (Figure 6B).

In view of recent observations that glucose transporter expression is increased in primary rabbit renal proximal tubule cell cultures under conditions of ER stress (Lee et al., 2009), the effect of TM and TG on the mRNA level of solute carrier family 2 member 1 (SLC2A1), which is basolaterally expressed in renal tubular cells throughout the whole nephron, was also investigated. As shown in Figures $6 \mathrm{C}$ and $6 \mathrm{D}$, the mRNA level of SLC2A1 in MDBK cells was markedly elevated by TG at the low and the high concentration tested and by TM only at the high concentration $(P<0.05)$.

A

$\begin{array}{llll}\text { CAV1 IL1B PYCARD } & \text { TNF }\end{array}$

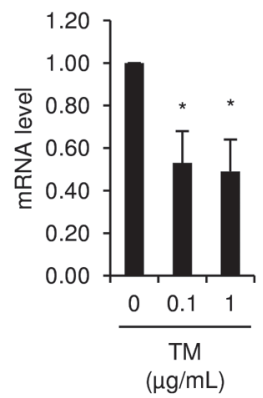

$\mathrm{B}$

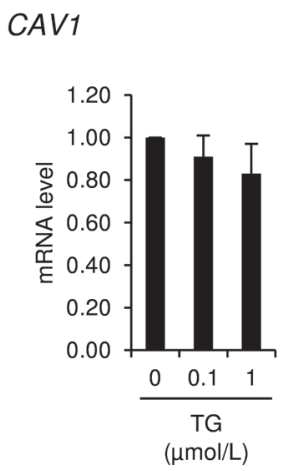

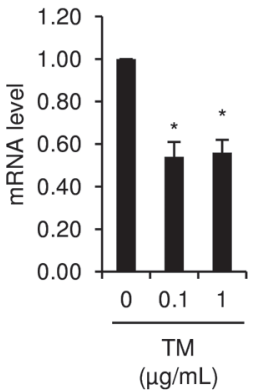

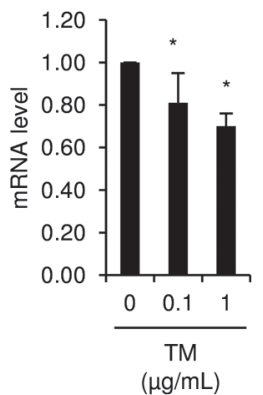

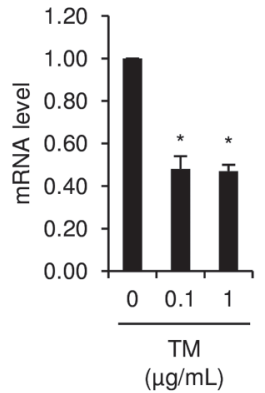

\section{C}

Figure 3. Effect of 24-h treatment with different concentrations of (A) tunicamycin (TM; 0, 0.1, and $1 \mu \mathrm{g} / \mathrm{mL})$ or $(\mathrm{B})$ thapsigargin (TG; $0,0.1$, and $1 \mu \mathrm{mol} / \mathrm{L}$ ) on relative mRNA levels of nuclear factor- $\mathrm{BB}(\mathrm{NF}-\kappa \mathrm{B})$ and NOD-like receptor P3 (NLRP3) inflammasome target genes caveolin $(C A V 1)$, interleukin $1 \beta(I L 1 B)$, tumor necrosis factor $(T N F)$, and PYD and CARD domain containing $(P Y C A R D)$ in Madin-Darby bovine kidney (MDBK) cells. Cells treated with dimethyl sulfoxide $(0.5 \%$ for TM and $0.1 \%$ for TG) as vehicle served as the control $(0 \mu \mathrm{g} / \mathrm{mL}$ of TM, $0 \mu \mathrm{mol} / \mathrm{L}$ of TG). Representative gel blots depicting protein level of NF- $\kappa \mathrm{B}$ subunit p50 in nuclear extracts of MDBK cells after $24-\mathrm{h}$ treatment with (C) $1 \mu \mathrm{g} / \mathrm{mL}$ of TM or (D) $1 \mu \mathrm{mol} / \mathrm{L}$ of TG. Abundance of $\beta$-actin protein served as a loading control. Bars represent relative protein level expressed as fold of the control $(0 \mu \mathrm{g} / \mathrm{mL}$ of TM, $0 \mu \mathrm{mol} / \mathrm{L}$ of $\mathrm{TG})$ and are means $\pm \mathrm{SD}$ from 3 independent experiments. ${ }^{*} P<0.05$. 


\section{ER Stress Inducers Modulate the Expression of Hydroxylases and Increase 1,25(OH) ${ }_{2} \mathrm{D}_{3}$ Concentration in the Supernatant of MDBK Cells}

To finally explore whether ER stress in MDBK cells affects the expression of enzymes involved in governing plasma $1,25(\mathrm{OH})_{2} \mathrm{D}_{3}$ concentration, the effect of $\mathrm{TM}$ and TG on the mRNA levels of 2 critical hydroxylases, namely 24-hydroxylase (encoded by CYP24A1) and $1 \alpha$-hydroxylase (encoded by $C Y P{ }^{2} 7 B 1$ ), and of the vitamin $\mathrm{D}$ receptor $(V D R)$ was studied. Although the mRNA level of $C Y$ P27B1 was markedly increased, that of $C Y P^{24 A 1}$ was strongly decreased by TM and TG at both concentrations tested in MDBK cells $(P<0.05$, Figures $7 \mathrm{~A}$ and $7 \mathrm{~B})$. The mRNA level of $V D R$ was also markedly elevated by both ER stress inducers in MDBK cells $(P<0.05$, Figures $7 \mathrm{~A}$ and $7 \mathrm{~B})$. The concentration of $1,25(\mathrm{OH})_{2} \mathrm{D}_{3}$ in the supernatant of MDBK cells treated with either $1 \mu \mathrm{g} / \mathrm{mL}$ of TM or $1 \mu \mathrm{mol} / \mathrm{L}$ of TG for $24 \mathrm{~h}$ was elevated by 14 and $11 \%(P<0.05$, Figure 7C), respectively.

\section{DISCUSSION}

In the present study, the effect of ER stress induction was investigated in the bovine MDBK cell line, which is a widely used cell model in ruminant research (Bionaz et al., 2008; Thering et al., 2009), to characterize the effects of ER stress in cattle at the cellular level. Our

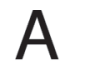

MGST3

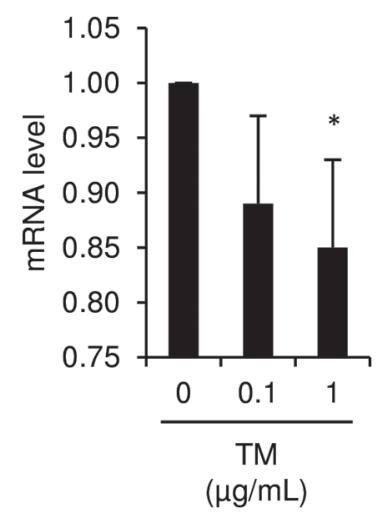

B
MT2A

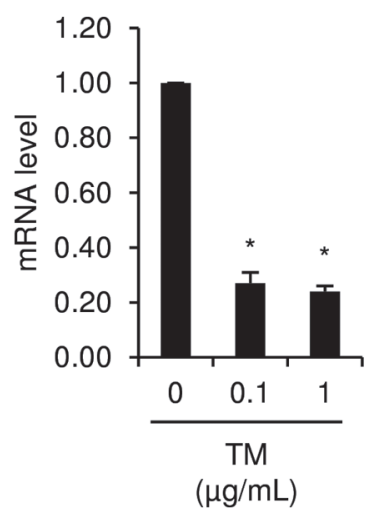

MT2A

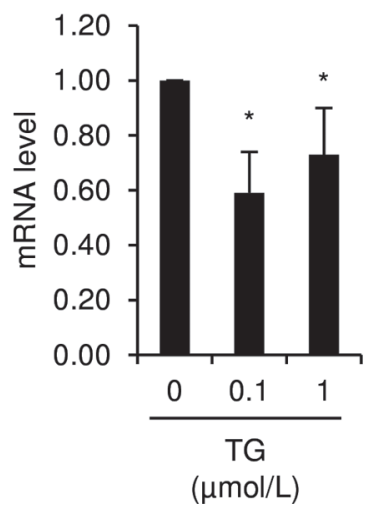

SOD1

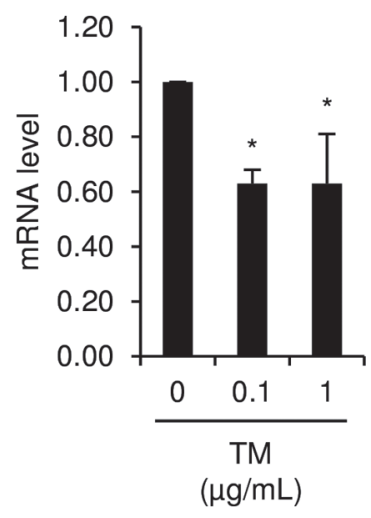

SOD1

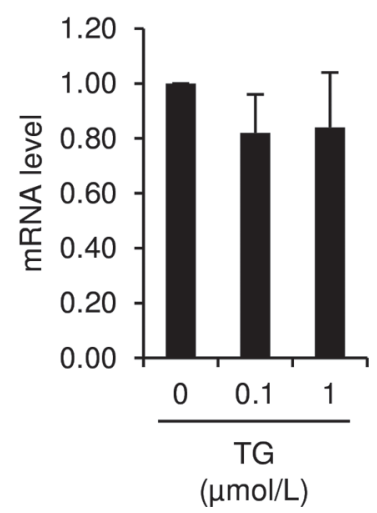

Figure 4. Effect of 24-h treatment with different concentrations of (A) tunicamycin (TM; 0, 0.1, and $1 \mu \mathrm{g} / \mathrm{mL})$ or $(\mathrm{B})$ thapsigargin $(\mathrm{TG}$; $0,0.1$, and $1 \mu \mathrm{mol} / \mathrm{L}$ ) on relative mRNA levels of nuclear factor E2-related factor 2 (Nrf2) target genes microsomal glutathione S-transferase 3 (MGST3), metallothionein 2A (MT2A), and superoxide dismutase 1 (SOD1) in Madin-Darby bovine kidney cells. Cells treated with dimethyl sulfoxide $(0.5 \%$ for TM and $0.1 \%$ for TG) as vehicle served as the control $(0 \mu \mathrm{g} / \mathrm{mL}$ of TM, $0 \mu \mathrm{mol} / \mathrm{L}$ of TG). Bars represent relative mRNA level expressed as fold of the control $(0 \mu \mathrm{g} / \mathrm{mL}$ of $\mathrm{TM}, 0 \mu \mathrm{mol} / \mathrm{L}$ of $\mathrm{TG})$ and are means $\pm \mathrm{SD}$ from 3 independent experiments. ${ }^{*} P<0.05$. 

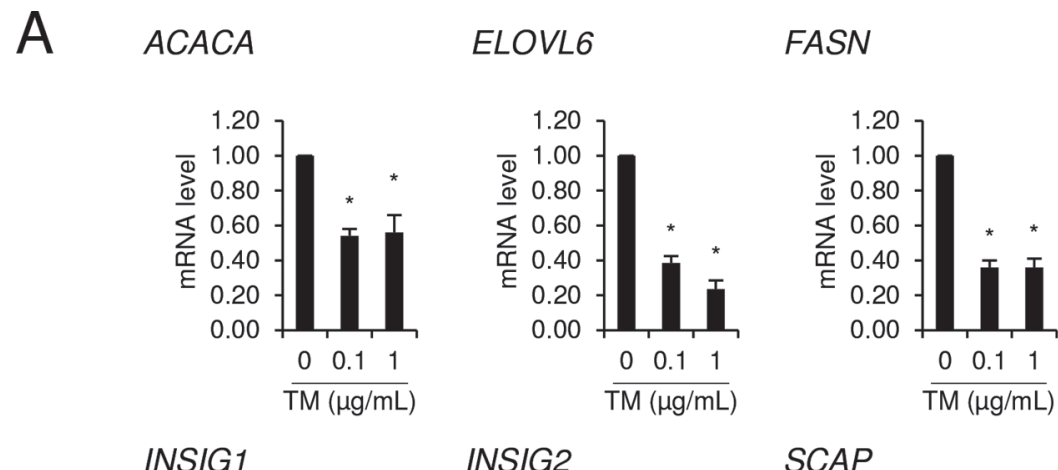

G6PD

INSIG1

INSIG2

SCAP
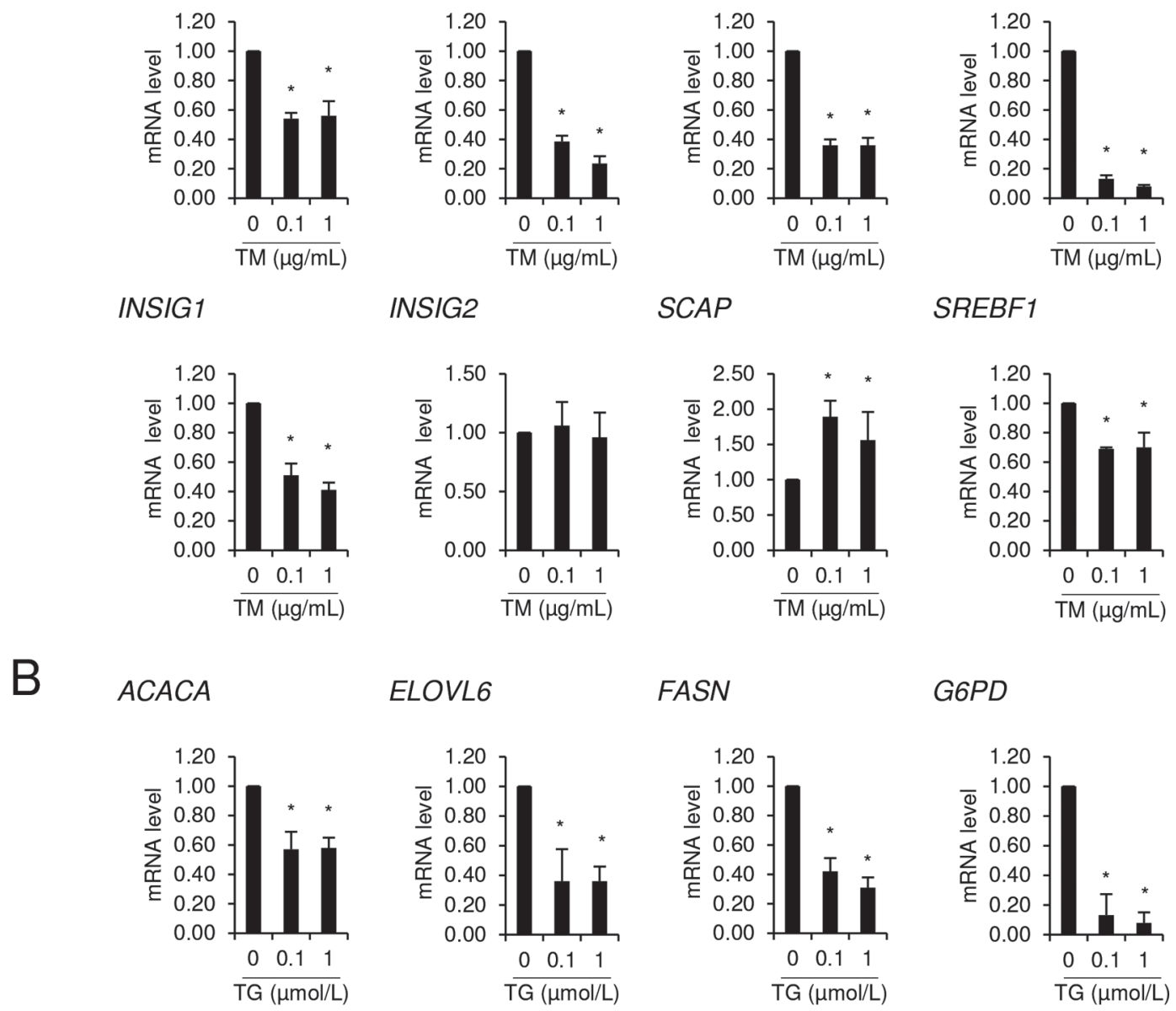

SREBF1

ELOVL6

FASN
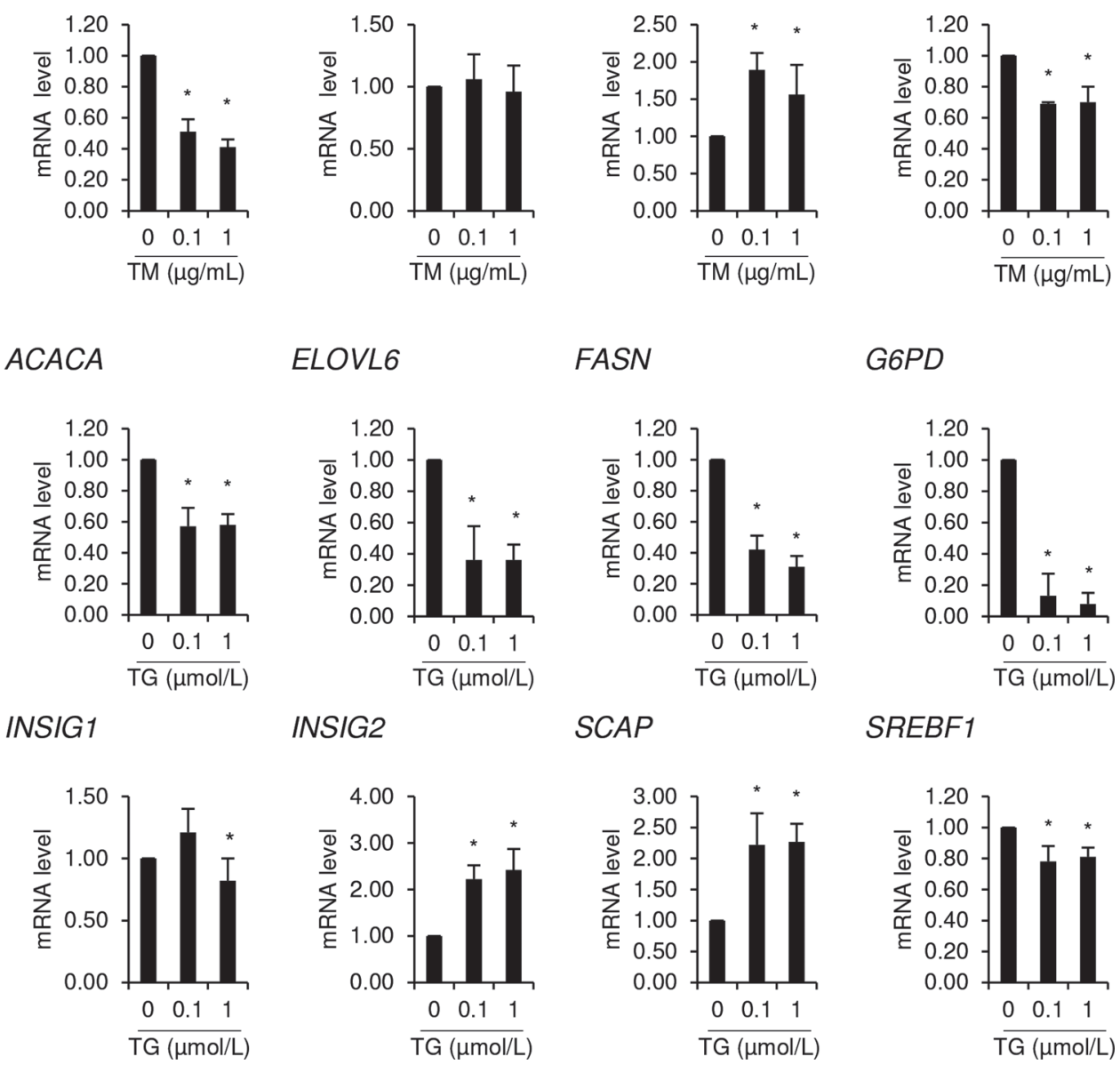

INSIG2

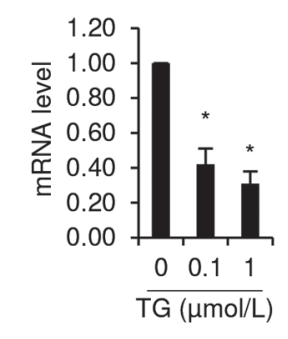

G6PD

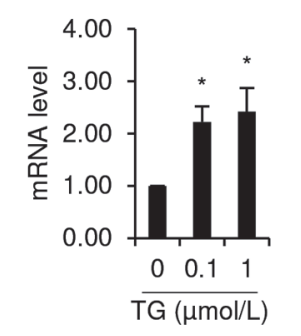

SCAP

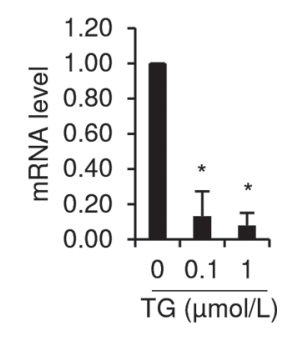

SREBF1
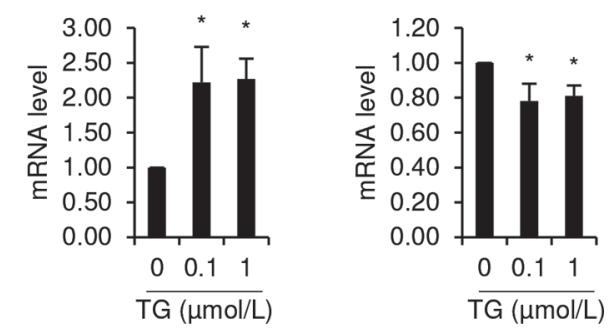

Figure 5. Effect of 24-h treatment with different concentrations of (A) tunicamycin (TM; 0, 0.1, and $1 \mu \mathrm{g} / \mathrm{mL})$ or (B) thapsigargin (TG; 0, 0.1 , and $1 \mu \mathrm{mol} / \mathrm{L}$ ) on relative mRNA levels of sterol regulatory element-binding factor 1 (SREBF1); its target genes acetyl-CoA carboxylase $\alpha$ $(A C A C A)$, ELOVL fatty acid elongase $6(E L O V L 6)$, fatty acid synthase $(F A S N)$, glucose-6-phosphate dehydrogenase $(G 6 P D)$; and the regulators of SREBF1 processing, insulin induced gene 1 (INSIG1), INSIG2, and SREBF cleavage activating protein $(S C A P)$ in Madin-Darby bovine kidney cells. Cells treated with dimethyl sulfoxide $(0.5 \%$ for TM and $0.1 \%$ for TG) as vehicle served as the control $(0 \mu \mathrm{g} / \mathrm{mL}$ of TM, $0 \mu \mathrm{mol} / \mathrm{L}$ of TG). Bars represent relative mRNA level expressed as fold of the control $(0 \mu \mathrm{g} / \mathrm{mL}$ of TM, $0 \mu \mathrm{mol} / \mathrm{L}$ of TG) and are means \pm SD from 3 independent experiments. ${ }^{*} P<0.05$.

results show that treatment of MDBK cells with the ER stress inducers TG and TM causes ER stress and the concomitant activation of the UPR. The responses of all ER stress indicators [induction of ER stress target genes, XBP1 splicing, and PERK phosphorylation
(Cnop et al., 2012)] to both concentrations of TG and TM, respectively, were similar, indicating that the maximum level of induction of ER stress was reached even at the low concentration of ER stress inducers used. 
A

CALB1

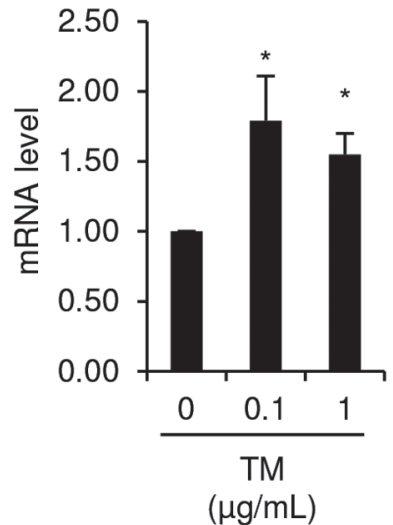

CALB1

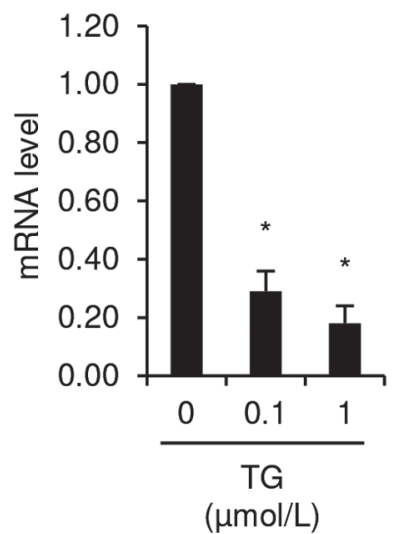

PMCA1

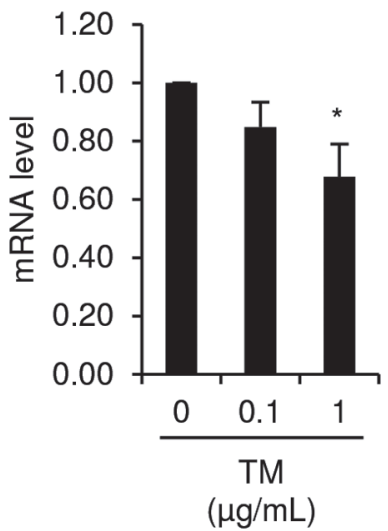

PMCA1

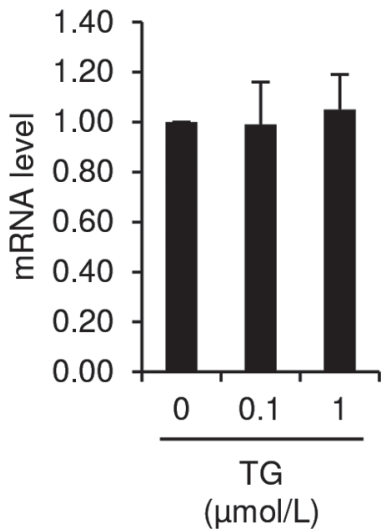

C

\section{SLC2A1}

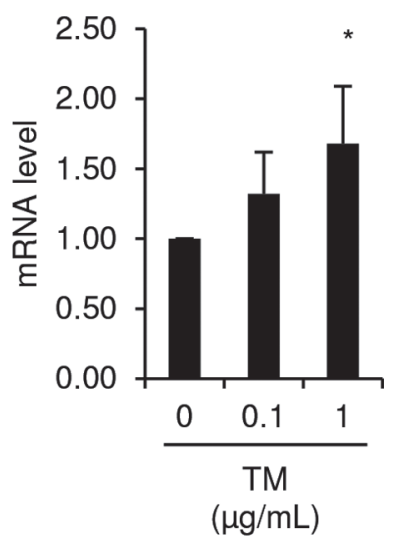

D

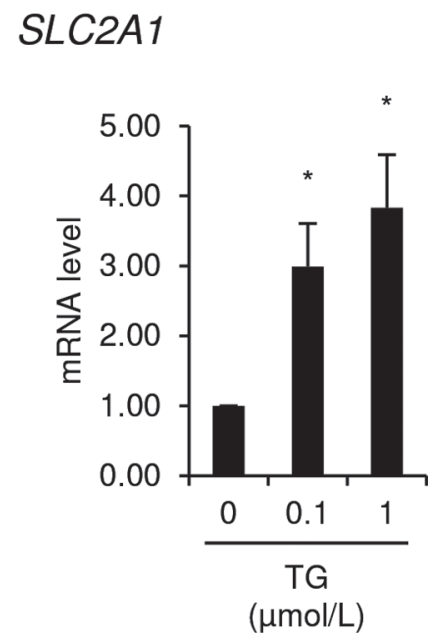

Figure 6. Effect of 24-h treatment with different concentrations of (A, C) tunicamycin (TM; 0, 0.1, and $1 \mu \mathrm{g} / \mathrm{mL})$ or $(\mathrm{B}, \mathrm{D})$ thapsigargin (TG; $0,0.1$, and $1 \mu \mathrm{mol} / \mathrm{L}$ ) on relative mRNA levels of renal tubular $\mathrm{Ca}^{2+}$ transport and glucose transport-associated genes plasma membrane $\mathrm{Ca}^{2+}$-transporting ATPase 1 (PMCA1), calbindin 1 (CALB1), and solute carrier family 2 member 1 (SLC2A1) in Madin-Darby bovine kidney

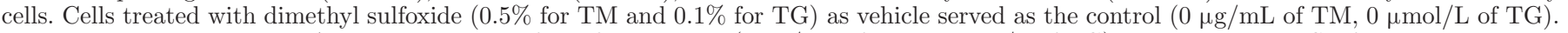
Bars represent relative mRNA level expressed as fold of the control $(0 \mu \mathrm{g} / \mathrm{mL}$ of TM, $0 \mu \mathrm{mol} / \mathrm{L}$ of TG $)$ and are means \pm SD from 3 independent experiments. ${ }^{*} P<0.05$.

With regard to characterizing cellular effects of ER stress in MDBK cells, we first investigated the effect of TG and TM on inflammatory signaling pathways, because induction of inflammation in response to ER stress has been frequently observed (Kaneko and Nomura, 2003; Li et al., 2009; Tam et al., 2012). An earlier study in HEK293T human embryonic kidney cells revealed that both TG and TM activate NF- $\kappa \mathrm{B}$ in an IRE1-dependent manner (Kaneko and Nomura, 2003). In addition, TM was reported to cause formation of ROS (Panzhinskiy et al., 2013), which are capable of activating the NF-кB pathway, mainly through the classical inhibitor of nuclear factor kappa-B kinase-dependent pathway. In contrast to this, our results with regard to the NF- $\kappa$ B pathway and the NLRP3 inflammasome pathway, which is also a critical inflammatory signaling pathway activated in response to different metabolic and inflammatory signals and leads to the formation of pro-inflammatory cytokines (Martinon et al., 2002), suggest that TG and TM exert an anti-inflammatory action in MDBK cells. Although this finding in MDBK cells is in conflict to the frequently observed stimulatory effect of ER stress on inflammation, it is in line with results from other studies also using kidney cells, 
A

CYP24A1

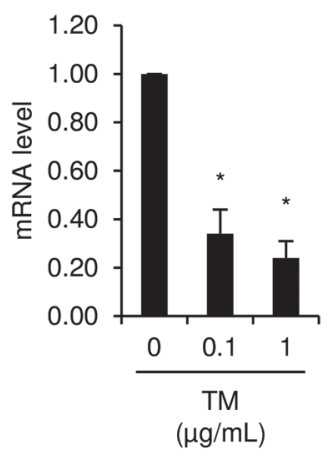

B

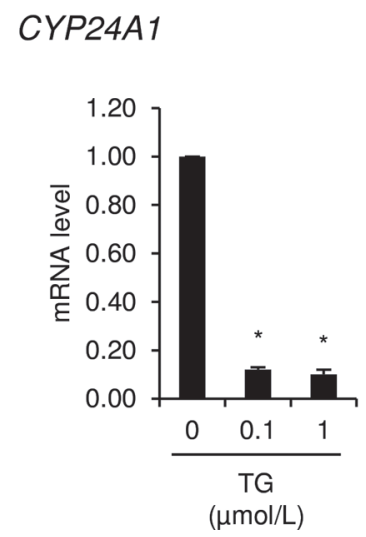

CYP27B1

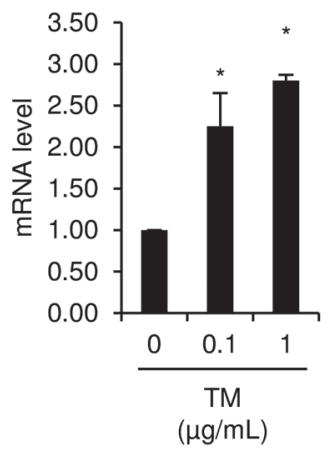

CYP27B1

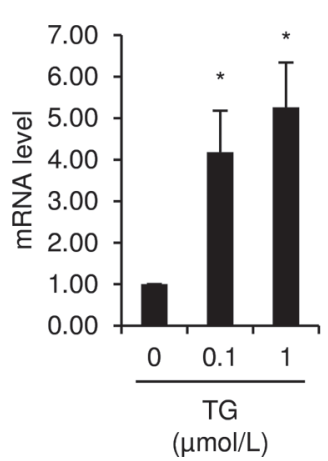

VDR

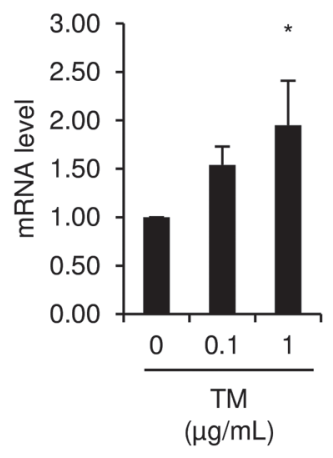

VDR

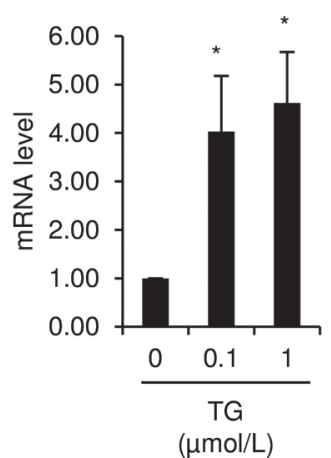

$1,25(\mathrm{OH}) 2 \mathrm{D}$

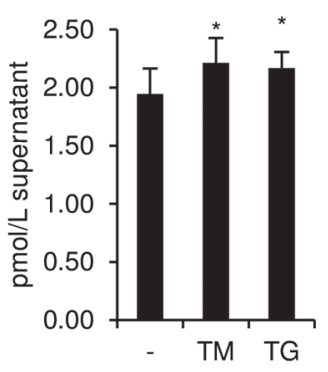

Figure 7. Effect of 24-h treatment with different concentrations of (A) tunicamycin (TM; 0, 0.1, and $1 \mu \mathrm{g} / \mathrm{mL})$ or $(\mathrm{B})$ thapsigargin $(\mathrm{TG}$; $0,0.1$, and $1 \mu \mathrm{mol} / \mathrm{L}$ ) on relative mRNA levels of $1,25(\mathrm{OH})_{2} \mathrm{D}_{3}$ plasma concentration-regulating genes cytochrome P450 family 24 subfamily A member 1 (CYP24A1), cytochrome P450 family 27 subfamily B member 1 (CYP27B1), and vitamin D receptor (VDR) in Madin-Darby bovine kidney (MDBK) cells. Cells treated with dimethyl sulfoxide $(0.5 \%$ for TM and $0.1 \%$ for TG) as vehicle served as the control $(0 \mu \mathrm{g} / \mathrm{mL}$ of TM, 0 $\mu \mathrm{mol} / \mathrm{L}$ of TG). Effect of $24-\mathrm{h}$ treatment with (C) $1 \mu \mathrm{g} / \mathrm{mL}$ of TM or (D) $1 \mu \mathrm{mol} / \mathrm{L}$ of TG on concentration of $1,25(\mathrm{OH})_{2} \mathrm{D}_{3}$ in the supernatant of MDBK cells. Bars represent relative mRNA level expressed as fold of the control $(0 \mu \mathrm{g} / \mathrm{mL}$ of TM, $0 \mu \mathrm{mol} / \mathrm{L}$ of TG $)$ and are means \pm SD from 3 independent experiments. ${ }^{*} P<0.05$.

like glomerular cells or mesangial cells of rats. For instance, ER stress was reported to confer resistance of glomerular cells to inflammatory stimuli (Inagi et al., 2008; Hayakawa et al., 2009). In addition, ER stress was demonstrated to inhibit NF- $\kappa \mathrm{B}$ activation in human and rat mesangial cells either through preferential induction of CCAAT/enhancer binding protein $\beta$ (Hayakawa et al., 2010), which is known to interact with $\mathrm{NF}-\kappa \mathrm{B}$, thereby inhibiting NF- $\kappa \mathrm{B}$ activation, or by activation of XBP1 and subsequent inhibition of IRE1 (Yu et al., 2015). Thus, in connection with findings from studies with kidney cells, our results indicate that inhibition of inflammation by ER stress in MDBK cells is probably a renal cell-specific phenomenon.

A further cellular effect that is frequently observed in the course of ER stress is the activation of cytoprotective pathways, such as Nrf2 signaling. The Nrf2 is a redox-sensitive transcription factor that controls the transcription of various antioxidative and cytoprotective proteins (Niture et al., 2010). The aim of Nrf2 activation is to counteract oxidative stress and inflammatory conditions resulting from increased formation of ROS and pro-inflammatory cytokines under ER stress (Cullinan et al., 2003; Cullinan and Diehl, 2006). Regarding this pathway, our results indicate that TG and TM inhibit Nrf2 signaling in MDBK cells. Although this finding is in contrast to the frequently observed activation of Nrf2 during ER stress, it is in agreement with the observed inhibition of NF- $\kappa \mathrm{B}$ signaling by TG and TM, because NF- $\kappa \mathrm{B}$ inhibition results in less formation of ROS and pro-inflammatory cytokines, which are potent activators of Nrf2 (Kaspar et al., 2009).

Convincing evidence exists that ER stress is involved in promoting de novo lipogenesis both in hepatic and 
nonhepatic tissues (Kammoun et al., 2009; Yu et al., 2013). As underlying mechanism, the proteolytic activation of key regulators of lipogenesis, such as SREBF1, which mainly control the expression of lipogenic genes, such as ACACA, ELOVL6, FASN, and G6PD, upon ER stress has been identified in mouse liver and cultured human hepatocytes (Lee and Ye, 2004; Kammoun et al., 2009; Fang et al., 2013). Activation/phosphorylation of the ER stress transducer PERK was found to be critical for this effect because deletion of PERK reduced expression of lipogenic enzymes, such as FASN (Bobrovnikova-Marjon et al., 2008). In the present study, we found that both TG and TM reduced the mRNA levels of SREBF1, ACACA, ELOVL6, FASN, and $G 6 P D$, which suggests that de novo lipogenesis is inhibited under ER stress conditions in MDBK cells. Again, this cellular effect of ER stress in MDBK cells is in sharp contrast to many published studies dealing with ER stress and lipogenesis in nonrenal cells (Kammoun et al., 2009; Yu et al., 2013; Choi et al., 2014). However, a key event responsible for the cell type-specific effect of ER stress inducers in MDBK cells might be the renal cell-specific inhibition of NF$\kappa \mathrm{B}$, a critical stimulator for the generation of ROS, in response to both TG and TM. In this regard, it is noteworthy that uric acid was found to stimulate ER stress-mediated SREBF1 activation and lipogenesis in hepatocellular carcinoma (HepG2) cells, but that uric acid-induced ROS generation preceded the induction of ER stress and treatment of HepG2 cells with different antioxidants blocked ER stress and alleviated uric acid-induced triacylglycerol accumulation in HepG2 cells (Choi et al., 2014). This suggested that ROS are responsible for the uric acid-induced ER stress and lipogenesis in HepG2 cells. Based on these findings, it is possible that the MDBK cell-specific inhibition of NF$\kappa \mathrm{B}$ by ER stress inducers and the consequently reduced formation of ROS, even not measured, is responsible for the lack of induction of SREBF1-mediated lipogenesis by TG and TM.

To explain the TG and TM-mediated inhibition of SREBF1-dependent gene transcription, we also determined the mRNA levels of SCAP, INSIG1, and INSIG2 because regulation of SREBF1 activity is controlled within the ER by the interaction of the inactivated SREBF1 with SCAP and INSIG (Hua et al., 1996; Yabe et al., 2002; Yang et al., 2002). The INSIG can cause retention of the SREBF-SCAP complex in the ER and prevent SCAP-mediated escort of inactive SREBF1 to the Golgi for proteolytic activation of SREBF1 to its active form (Lee and Ye, 2004). Indeed, overexpression of INSIG1 represses hepatic SREBF1 activation and lipogenesis (Engelking et al., 2004). However, in our study the 2 INSIG isoforms were not consistently regulated by the different ER stress inducers (INSIG2 was upregulated by TG, INSIG1 was downregulated by TM), making it difficult to explain the inhibitory effect of both ER stress inducers on SREBF1-dependent gene transcription. In contrast, the SCAP mRNA level was elevated by both ER stress inducers, an observation that was unexpected because SCAP induction is known to be associated with SREBF1 activation (Song et al., 2016). Hence, our findings cannot mechanistically explain the observed inhibition of SREBF1 pathway by ER stress inducers in MDBK cells, and further studies are necessary to resolve the underlying mode of action.

With regard to the effect of ER stress on renal cellspecific functions, we observed that both ER stress inducers strongly induce mRNA expression of SLC2A1, which facilitates transport of glucose out of cells of the proximal convoluted tubules (Thorens et al., 1990; Linden et al., 2006), but is expressed basolaterally throughout the whole nephron (Linden et al., 2006). Interestingly, SLC2A1 expression has been reported to be elevated in the kidney tubules of diabetic animals (Linden et al., 2006), and treatment of diabetic rats with insulin was found to reduce SLC2A1 expression in the tubules (Dominguez et al., 1994). Because hyperglycemia induces ER stress in renal epithelial cells (Lindenmeyer et al., 2008), it is likely that the increased SLC2A1 expression in MDBK cells treated with TG and TM is a consequence of ER stress. It is noteworthy that recent studies showed ER stress also causes upregulation of sodium-dependent glucose transporters ( $S G L T)$ 1 and 2 in several cell types (Schaffer et al., 2000; Hall et al., 2001; Yu et al., 2005) including proximal kidney tubular cells (Lee et al., 2009), and this effect has been interpreted as a cytoprotective mechanism to cover the metabolic demands during ER stress (Lee et al., 2009). However, because distal tubular MDBK cells, unlike proximal tubular cells, are not involved in the reuptake of glucose or AA from the urinary filtrate, we did not consider SGLT expression in our study.

Transcellular $\mathrm{Ca}^{2+}$ transport is a further transport process playing an important or even exclusive role in distal kidney tubules. Through this process, which is known to be stimulated by $1,25(\mathrm{OH})_{2} \mathrm{D}_{3}$ and parathyroid hormone (Hoenderop et al., 2005), about 98 to $99 \%$ of filtered $\mathrm{Ca}^{2+}$ is reabsorbed by the kidney tubules (Blaine et al., 2015). Commensurate with the distal origin of MDBK cells, these cells have been reported to express 2 basolateral $\mathrm{Ca}^{2+}$ transporters, PMCA1 and SLC8A1, and the intracellular $\mathrm{Ca}^{2+}$ binding protein CALB1 (Glendenning et al., 2000). Moreover, in line with the role of the kidney as a target tissue for the effects of $1,25(\mathrm{OH})_{2} \mathrm{D}_{3}$ in regulating extracellular $\mathrm{Ca}^{2+}$ homeostasis, treatment of MDBK cells with $1,25(\mathrm{OH})_{2} \mathrm{D}_{3}$ enhances the expression of 
PMCA1 and CALB1 in MDBK cells (Gagnon et al., 1994; Glendenning et al., 2000). Interestingly, we found that TG markedly decreased, but TM increased the expression of $C A L B 1$, whereas the unaltered (by TG) or only slightly regulated (by TM) expression of PMCA1 indicated that ER stress presumably does not influence plasma membrane $\mathrm{Ca}^{2+}$ transport in distal tubular cells. The observed regulation of $C A L B 1 \mathrm{mRNA}$ by ER stress inducers in MDBK cells may be the consequence of the perturbation of intracellular $\mathrm{Ca}^{2+}$ homeostasis, such as excessive cytosolic $\mathrm{Ca}^{2+}$ accumulation due to $\mathrm{Ca}^{2+}$ depletion of the ER during ER stress (Yoshida et al., 2006). Excessive depletion of ER $\mathrm{Ca}^{2+}$ stores contributes to cell death via apoptosis due to activation of caspases and other proapoptotic signaling pathways under prolonged ER stress (Deniaud et al., 2008). However, rapid restoration of intracellular $\mathrm{Ca}^{2+}$ due to SERCA-mediated influx of $\mathrm{Ca}^{2+}$ into the ER can protect against ER stress-induced apoptosis. In this regard it is interesting that SK2 channel activation, which stimulates $\mathrm{Ca}^{2+}$ uptake via SERCA and $\mathrm{Ca}^{2+}$ retention in the ER, protects against ER stress-induced apoptosis only, when ER stress is induced by TM, an inhibitor of N-linked glycosylation, but not TG, which is an irreversible blocker of SERCA (Lytton et al., 1991). Thus, this different mode of action between TG and TM may explain their differential effect on $C A L B 1$ expression in MDBK cells. It is possible that the increased expression of CALB1 in response to TM may reflect an adaptation to the transient increase of cytosolic $\mathrm{Ca}^{2+}$ levels in MDBK cells following induction of ER stress. As a consequence, the impairment of cell viability by the high concentration of TM ( $-18 \%$ vs. control) was only moderate, indicating that MDBK cells were able to cope with the TM-induced ER stress and perturbation of $\mathrm{Ca}^{2+}$ homeostasis. In contrast, the markedly depressed expression of CALB1 by TG may indicate that the TG-induced blockade of SERCA-mediated $\mathrm{Ca}^{2+}$ re-entry into the ER caused a marked depletion of ER $\mathrm{Ca}^{2+}$ stores and a prolonged increase of cytosolic $\mathrm{Ca}^{2+}$ levels, which overcharged the cytoprotective mechanisms of the cell, thereby inducing pro-apoptotic pathways. In line with this, we found that the viability of MDBK cells treated with the high concentration of TG ( $-32 \%$ vs. control) was more strongly affected than with TM, suggesting that TG-induced ER stress caused apoptosis-mediated cell death more efficiently.

Kidney tubular cells also play a critical role in governing plasma concentration of $1,25(\mathrm{OH})_{2} \mathrm{D}_{3}$ through CYP27B1-mediated $1 \alpha$-hydroxylation of $25(\mathrm{OH}) \mathrm{D}_{3}$, which is formed in the liver and secreted into the blood, and through catalyzing the breakdown of $1,25(\mathrm{OH})_{2} \mathrm{D}_{3}$ by CYP24A1 (Jones et al., 2012). According to the clas- sical concept of vitamin D metabolism in the kidney, the proximal tubule is considered to be the exclusive site of $1,25(\mathrm{OH})_{2} \mathrm{D}_{3}$ synthesis (Kawashima et al., 1981). However, this concept became obsolete with the cloning of CYP27B1 (Takeyama et al., 1997) and providing evidence of $C Y{ }^{2}{ }^{27 B 1} \mathrm{mRNA}$ and protein expression in different locations along the nephron including the distal tubule (Zehnder et al., 1999). In line with this, we could demonstrate mRNA expression of CYP27B1 in MDBK cells, which has not been described yet in the literature. Noteworthy, we found that CYP27B1 was strongly induced, whereas CYP24A1 was markedly repressed by both ER stress inducers, suggesting that under conditions of ER stress the formation of $1,25(\mathrm{OH})_{2} \mathrm{D}_{3}$ is stimulated. In line with this, we observed that the concentration of $1,25(\mathrm{OH})_{2} \mathrm{D}_{3}$ in the supernatant of MDBK cells was increased by approximately $15 \%$ by both TG and TM. To the best of our knowledge, neither $1,25(\mathrm{OH})_{2} \mathrm{D}_{3}$ synthesis in MDBK cells nor this effect of ER stress on the formation of $1,25(\mathrm{OH})_{2} \mathrm{D}_{3}$ have been described in the literature and we cannot provide any mechanistic explanation. Despite literature data showing that $1,25(\mathrm{OH})_{2} \mathrm{D}_{3}$ increases $C A L B 1$ mRNA (Gagnon et al., 1994), we believe that the weak stimulatory effect $(+15 \%)$ of both ER stress-inducing compounds on $1,25(\mathrm{OH})_{2} \mathrm{D}_{3}$ formation has no influence on CALB1 mRNA, in particular because TG and TM had an opposite effect on $C A L B 1$ mRNA levels. Rather, we believe that the opposite effect of TG and TM is due to their different mode of action and the associated change of cytosolic $\mathrm{Ca}^{2+}$ levels as discussed above. Interestingly, our study further revealed that both ER stress inducers cause an upregulation of the $V D R$ in MDBK cells. The $V D R$ is known to mediate the effect of $1,25(\mathrm{OH})_{2} \mathrm{D}_{3}$ on the expression of genes involved in $\mathrm{Ca}^{2+}$ transport and CYP27B1 and CYP24A1 (Henry and Norman, 1984), which is the basis for the classical action of $1,25(\mathrm{OH})_{2} \mathrm{D}_{3}$ in regulating $\mathrm{Ca}^{2+}$ homeostasis in the kidney and intestine. However, $1,25(\mathrm{OH})_{2} \mathrm{D}_{3}$ has been increasingly recognized to mediate several nonclassical actions, including the modulation of innate immune processes, such as inflammation (Hewison, 2010). With regard to the kidney, it was shown recently that $1,25(\mathrm{OH})_{2} \mathrm{D}_{3}$ represses LPS-induced activation of $\mathrm{NF}-\kappa \mathrm{B}$ in the renal tubules providing a mechanistic explanation for $1,25(\mathrm{OH})_{2} \mathrm{D}_{3}$-mediated anti-inflammatory activity during LPS-induced acute kidney injury (Xu et al., 2015). In view of the observed increased expression of $V D R$ under conditions of ER stress in MDBK cells, one might speculate that these cells would be more sensitive to the action of $1,25(\mathrm{OH})_{2} \mathrm{D}_{3}$. In this context, an increased sensitivity of MDBK cells to the anti-inflammatory action of $1,25(\mathrm{OH})_{2} \mathrm{D}_{3}$ could be interpreted 


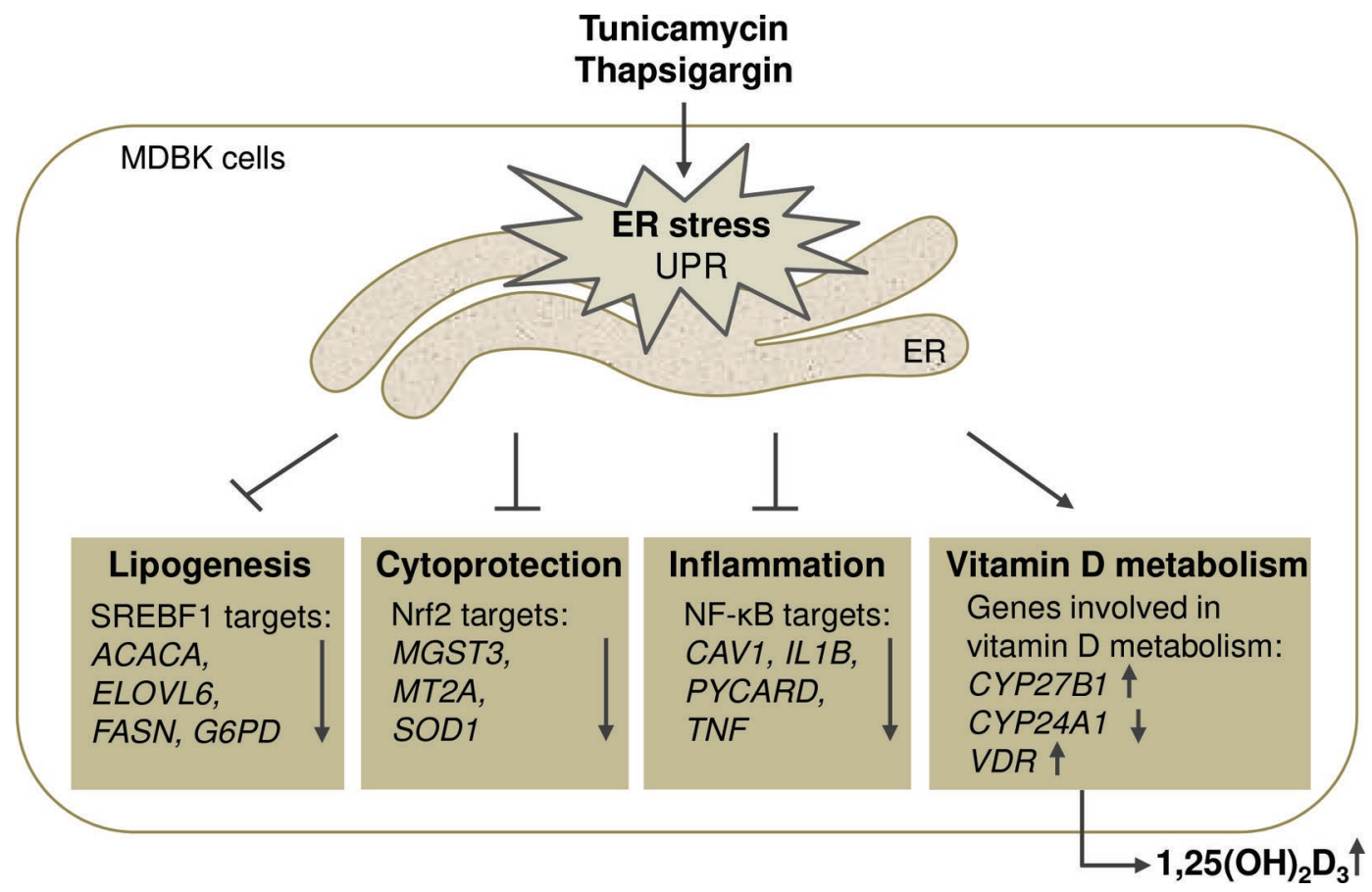

Figure 8. Schematic summary of the effects of endoplasmic reticulum (ER) stress inducers in Madin-Darby bovine kidney (MDBK) cells. Under conditions of ER stress with the initiated unfolded protein response (UPR), critical signaling pathways, such as nuclear factor- $\kappa \mathrm{B}$ ( $N F$ $\kappa B$ ), nuclear factor E2-related factor 2 (Nrf2), and sterol regulatory element-binding protein (SREBF1), are inhibited, whereas the formation of $1,25(\mathrm{OH})_{2} \mathrm{D}_{3}$ is stimulated in MDBK cells. $A C A C A=$ acetyl-CoA carboxylase $\alpha ; E L O V L 6=$ fatty acid elongase $6 ; F A S N=$ fatty acid synthase; $G 6 P D=$ glucose-6-phosphate dehydrogenase; $M G S T 3=$ microsomal glutathione S-transferase 3; $M T 2 A=$ metallothionein 2A; SOD1 = superoxide dismutase 1 , soluble; $C A V 1=$ caveolin; $I L 1 B=$ interleukin $1 \beta ; P Y C A R D=$ PYD and CARD domain containing; TNF = tumor necrosis factor; $C Y P 24 A 1=$ cytochrome P450 family 24 subfamily A member $1 ; C Y P 27 B 1=$ cytochrome P450 family 27 subfamily B member 1 ; VDR $=$ vitamin $\mathrm{D}\left(1,25\right.$-dihydroxyvitamin $\left.\mathrm{D}_{3}\right)$ receptor. Color version available online.

as a cytoprotective mechanism to better cope with the cellular consequences of ER stress. Undoubtedly, more research is necessary to substantiate our assumption.

\section{CONCLUSIONS}

In conclusion, the present study indicates that under conditions of ER stress critical signaling pathways, such as NF- $\kappa$ B, Nrf2, and SREBF1, are inhibited in bovine MDBK cells. In Figure 8, a schematic summary of the effects of ER stress inducers on these signaling pathways and on kidney characteristic functions in MDBK cells is provided. The inhibitory effect of ER stress on these pathways in MDBK cells is in line with findings from studies using other kidney cells, but is in contrast to observations in hepatocytes, where ER stress has been found to stimulate NF- $\mathrm{B}$, Nrf2, and SREBF1. This suggests that bovine MDBK cells are not an appropriate model to clarify whether ER stress plays a pathophysiological role in the development of liver-associated diseases and systemic inflammation in postpartum dairy cows. Nevertheless, an interesting finding from the present study, which should receive further attention in future studies, is that the formation of $1,25(\mathrm{OH})_{2} \mathrm{D}_{3}$ is stimulated under conditions of ER stress.

\section{REFERENCES}

Altschul, S. F., W. Gish, W. Miller, E. W. Myers, and D. J. Lipman 1990. Basic local alignment search tool. J. Mol. Biol. 215:403-410.

Bionaz, M., C. R. Baumrucker, E. Shirk, J. P. Vanden Heuvel, E. Block, and G. A. Varga. 2008. Characterization of Madin-Darby bovine kidney cell line for peroxisome proliferator-activated receptors: Temporal response and sensitivity to fatty acids. J. Dairy Sci. 91:2808-2813.

Blaine, J., M. Chonchol, and M. Levi. 2015. Renal control of calcium, phosphate, and magnesium homeostasis. Clin. J. Am. Soc. Nephrol. 10:1257-1272.

Bobrovnikova-Marjon, E., G. Hatzivassiliou, C. Grigoriadou, M. Romero, D. R. Cavener, C. B. Thompson, and J. A. Diehl. 2008. PERK-dependent regulation of lipogenesis during mouse mammary gland development and adipocyte differentiation. Proc. Natl. Acad. Sci. USA 105:16314-16319.

Bradford, B. J., K. Yuan, J. K. Farney, L. K. Mamedova, and A. J. Carpenter. 2015. Invited review: Inflammation during the transition to lactation: New adventures with an old flame. J. Dairy Sci. 98:6631-6650.

Choi, Y. J., H. S. Shin, H. S. Choi, J. W. Park, I. Jo, E. S. Oh, K. Y. Lee, B. H. Lee, R. J. Johnson, and D. H. Kang. 2014. Uric acid induces fat accumulation via generation of endoplasmic reticu- 
lum stress and SREBP-1c activation in hepatocytes. Lab. Invest. 94:1114-1125.

Cláudio, N., A. Dalet, E. Gatti, and P. Pierre. 2013. Mapping the crossroads of immune activation and cellular stress response pathways. EMBO J. 32:1214-1224.

Cnop, M., F. Foufelle, and L. A. Velloso. 2012. Endoplasmic reticulum stress, obesity and diabetes. Trends Mol. Med. 18:59-68.

Cullinan, S. B., and J. A. Diehl. 2006. Coordination of ER and oxidative stress signaling: The PERK/Nrf2 signaling pathway. Int. J. Biochem. Cell Biol. 38:317-332.

Cullinan, S. B., D. Zhang, M. Hannink, E. Arvisais, R. J. Kaufman, and J. A. Diehl. 2003. Nrf2 is a direct PERK substrate and effector of PERK-dependent cell survival. Mol. Cell. Biol. 23:7198-7209.

de Virgilio, M., C. Kitzmüller, E. Schwaiger, M. Klein, G. Kreibich, and N. E. Ivessa. 1999. Degradation of a short-lived glycoprotein from the lumen of the endoplasmic reticulum: The role of $\mathrm{N}$ linked glycans and the unfolded protein response. Mol. Biol. Cell 10:4059-4073.

Deniaud, A., O. Sharaf el Dein, E. Maillier, D. Poncet, G. Kroemer, C. Lemaire, and C. Brenner. 2008. Endoplasmic reticulum stress induces calcium-dependent permeability transition, mitochondrial outer membrane permeabilization and apoptosis. Oncogene $27: 285-299$.

Dominguez, J. H., K. Camp, L. Maianu, H. Feister, and W. T. Garvey. 1994. Molecular adaptations of GLUT1 and GLUT2 in renal proximal tubules of diabetic rats. Am. J. Physiol. 266:F283-F290.

Engelking, L. J., H. Kuriyama, R. E. Hammer, J. D. Horton, M. S. Brown, J. L. Goldstein, and G. Liang. 2004. Overexpression of Insig-1 in the livers of transgenic mice inhibits SREBP processing and reduces insulin-stimulated lipogenesis. J. Clin. Invest. 113:1168-1175.

Fang, D. L., Y. Wan, W. Shen, J. Cao, Z. X. Sun, H. H. Yu, Q. Zhang, W. H. Cheng, J. Chen, and B. Ning. 2013. Endoplasmic reticulum stress leads to lipid accumulation through upregulation of SREBP-1c in normal hepatic and hepatoma cells. Mol. Cell. Biochem. 381:127-137.

Gagnon, A. M., M. Simboli-Campbell, and J. E. Welsh. 1994. Induction of calbindin D-28K in Madin-Darby bovine kidney cells by $1,25(\mathrm{OH})_{2} \mathrm{D}_{3}$. Kidney Int. 45:95-102.

Gessner, D. K., M. Bonarius, E. Most, A. Fiesel, and K. Eder. 2016. Effects of polyphenol-rich plant products from grape or hop as feed supplements on the expression of inflammatory, antioxidative, cytoprotective and endoplasmic reticulum stress-related genes and the antioxidative status in the liver of piglets. J. Anim. Physiol. Anim. Nutr. (Berl.) https://doi.org/10.1111/jpn.12586.

Gessner, D. K., G. Schlegel, R. Ringseis, F. J. Schwarz, and K. Eder. 2014. Up-regulation of endoplasmic reticulum stress induced genes of the unfolded protein response in the liver of periparturient dairy cows. BMC Vet. Res. 10:46.

Glendenning, P., T. Ratajczak, I. M. Dick, and R. L. Prince. 2000. Calcitriol upregulates expression and activity of the $1 \mathrm{~b}$ isoform of the plasma membrane calcium pump in immortalized distal kidney tubular cells. Arch. Biochem. Biophys. 380:126-132.

Hall, J. L., J. C. Chatham, H. Eldar-Finkelman, and G. H. Gibbons. 2001. Upregulation of glucose metabolism during intimal lesion formation is coupled to the inhibition of vascular smooth muscle cell apoptosis. Role of GSK3beta. Diabetes 50:1171-1179.

Hayakawa, K., N. Hiramatsu, M. Okamura, H. Yamazaki, S. Nakajima, J. Yao, A. W. Paton, J. C. Paton, and M. Kitamura. 2009. Acquisition of anergy to proinflammatory cytokines in nonimmune cells through endoplasmic reticulum stress response: A mechanism for subsidence of inflammation. J. Immunol. 182:1182-1191.

Hayakawa, K., S. Nakajima, N. Hiramatsu, M. Okamura, T. Huang, Y. Saito, Y. Tagawa, M. Tamai, S. Takahashi, J. Yao, and M. Kitamura. 2010. ER stress depresses NF-kappaB activation in mesangial cells through preferential induction of C/EBP beta. J. Am. Soc. Nephrol. 21:73-81.

Henry, H. L., and A. W. Norman. 1984. Vitamin D: Metabolism and biological actions. Annu. Rev. Nutr. 4:493-520.
Hewison, M. 2010. Vitamin D and the immune system: New perspectives on an old theme. Endocrinol. Metab. Clin. North Am. $39: 365-379$.

Hoenderop, J. G., B. Nilius, and R. J. Bindels. 2005. Calcium absorption across epithelia. Physiol. Rev. 85:373-422.

Hua, X., A. Nohturfft, J. L. Goldstein, and M. S. Brown. 1996. Sterol resistance in $\mathrm{CHO}$ cells traced to point mutation in SREBP cleavage-activating protein. Cell 87:415-426.

Inagi, R., T. Kumagai, H. Nishi, T. Kawakami, T. Miyata, T. Fujita, and M. Nangaku. 2008. Preconditioning with endoplasmic reticulum stress ameliorates mesangioproliferative glomerulonephritis. J. Am. Soc. Nephrol. 19:915-922.

Invernizzi, G., A. Naeem, and J. J. Loor. 2012. Short communication: Endoplasmic reticulum stress gene network expression in bovine mammary tissue during the lactation cycle. J. Dairy Sci. 95:2562-2566.

Jones, G., D. E. Prosser, and M. Kaufmann. 2012. 25-Hydroxyvitamin D-24-hydroxylase (CYP24A1): Its important role in the degradation of vitamin D. Arch. Biochem. Biophys. 523:9-18.

Jordan, R., L. Wang, T. M. Graczyk, T. M. Block, and P. R. Romano. 2002. Replication of a cytopathic strain of bovine viral diarrhea virus activates PERK and induces endoplasmic reticulum stressmediated apoptosis of MDBK cells. J. Virol. 76:9588-9599.

Kammoun, H. L., H. Chabanon, I. Hainault, S. Luquet, C. Magnan, T. Koike, P. Ferre, and F. Foufelle. 2009. GRP78 expression inhibits insulin and ER stress-induced SREBP-1c activation and reduces hepatic steatosis in mice. J. Clin. Invest. 119:1201-1215.

Kaneko, M., and Y. Nomura. 2003. ER signaling in unfolded protein response. Life Sci. 74:199-205.

Kaspar, J. W., S. K. Niture, and A. K. Jaiswal. 2009. Nrf2:INrf2 (Keap1) signaling in oxidative stress. Free Radic. Biol. Med. 47:1304-1309.

Kawashima, H., S. Torikai, and K. Kurokawa. 1981. Localization of 25-hydroxyvitamin D3 1 alpha-hydroxylase and 24-hydroxylase along the rat nephron. Proc. Natl. Acad. Sci. USA 78:1199-1203.

Lee, J. N., and J. Ye. 2004. Proteolytic activation of sterol regulatory element-binding protein induced by cellular stress through depletion of Insig-1. J. Biol. Chem. 279:45257-45265.

Lee, Y. J., H. N. Suh, and H. J. Han. 2009. Effect of BSA-induced ER stress on SGLT protein expression levels and alpha-MG uptake in renal proximal tubule cells. Am. J. Physiol. Renal Physiol. 296:F1405-F1416

Li, J., J. J. Wang, Q. Yu, M. Wang, and S. X. Zhang. 2009. Endoplasmic reticulum stress is implicated in retinal inflammation and diabetic retinopathy. FEBS Lett. 583:1521-1527.

Linden, K. C., C. L. DeHaan, Y. Zhang, S. Glowacka, A. J. Cox, D. J. Kelly, and S. Rogers. 2006. Renal expression and localization of the facilitative glucose transporters GLUT1 and GLUT12 in animal models of hypertension and diabetic nephropathy. Am. J. Physiol. Renal Physiol. 290:F205-F213.

Lindenmeyer, M. T., M. P. Rastaldi, M. Ikehata, M. A. Neusser, M. Kretzler, C. D. Cohen, and D. Schlondorff. 2008. Proteinuria and hyperglycemia induce endoplasmic reticulum stress. J. Am. Soc. Nephrol. 19:2225-2236.

Lytton, J., M. Westlin, and M. R. Hanley. 1991. Thapsigargin inhibits the sarcoplasmic or endoplasmic reticulum Ca-ATPase family of calcium pumps. J. Biol. Chem. 266:17067-17071.

Marciniak, S. J., and D. Ron. 2006. Endoplasmic reticulum stress signaling in disease. Physiol. Rev. 86:1133-1149.

Martinon, F., K. Burns, and J. Tschopp. 2002. The inflammasome: A molecular platform triggering activation of inflammatory caspases and processing of proIL-beta. Mol. Cell 10:417-426.

Mengesdorf, T., S. Althausen, I. Oberndorfer, and W. Paschen. 2001. Response of neurons to an irreversible inhibition of endoplasmic reticulum $\mathrm{Ca}(2+)$-ATPase: Relationship between global protein synthesis and expression and translation of individual genes. Biochem. J. 356:805-812.

Niture, S. K., J. W. Kaspar, J. Shen, and A. K. Jaiswal. 2010. Nrf2 signaling and cell survival. Toxicol. Appl. Pharmacol. 244:37-42. 
Pagliassotti, M. J. 2012. Endoplasmic reticulum stress in nonalcoholic fatty liver disease. Annu. Rev. Nutr. 32:17-33.

Pagliassotti, M. J., P. Y. Kim, A. L. Estrada, C. M. Stewart, and C. L. Gentile. 2016. Endoplasmic reticulum stress in obesity and obesity-related disorders: An expanded view. Metabolism 65:1238-1246.

Panzhinskiy, E., J. Ren, and S. Nair. 2013. Protein tyrosine phosphatase $1 \mathrm{~B}$ and insulin resistance: Role of endoplasmic reticulum stress/reactive oxygen species/nuclear factor kappa B axis. PLoS One 8:e77228.

Ron, D., and P. Walter. 2007. Signal integration in the endoplasmic reticulum unfolded protein response. Nat. Rev. Mol. Cell Biol. 8:519-529

Rozen, S., and H. Skaletsky. 2000. Primer3 on the WWW for general users and for biologist programmers. Pages 365-386 in Bioinformatics Methods and Protocols. S. Krawetz and S. Misener, ed. Humana Press, Totowa, NJ.

Schaffer, S. W., C. B. Croft, and V. Solodushko. 2000. Cardioprotective effect of chronic hyperglycemia: Effect on hypoxia-induced apoptosis and necrosis. Am. J. Physiol. Heart Circ. Physiol. 278:H1948-H1954.

Song, Y. F., Z. Luo, L. H. Zhang, C. Hogstrand, and Y. X. Pan. 2016. Endoplasmic reticulum stress and disturbed calcium homeostasis are involved in copper-induced alteration in hepatic lipid metabolism in yellow catfish Pelteobagrus fulvidraco. Chemosphere $144: 2443-2453$.

Sutton-McDowall, M. L., L. L. Wu, M. Purdey, A. D. Abell, E. M. Goldys, K. L. MacMillan, J. G. Thompson, and R. L. Robker. 2016. Nonesterified fatty acid-induced endoplasmic reticulum stress in cattle cumulus oocyte complexes alters cell metabolism and developmental competence. Biol. Reprod. 94:23.

Takeyama, K., S. Kitanaka, T. Sato, M. Kobori, J. Yanagisawa, and S. Kato. 1997. 25-Hydroxyvitamin D3 1alpha-hydroxylase and vitamin D synthesis. Science 277:1827-1830.

Tam, A. B., E. L. Mercado, A. Hoffmann, and M. Niwa. 2012. ER stress activates NF-kappaB by integrating functions of basal IKK activity, IRE1 and PERK. PLoS One 7:e45078.

Thering, B. J., M. Bionaz, and J. J. Loor. 2009. Long-chain fatty acid effects on peroxisome proliferator-activated receptor-alpharegulated genes in Madin-Darby bovine kidney cells: Optimization of culture conditions using palmitate. J. Dairy Sci. 92:2027-2037.

Thorens, B., Z. Q. Cheng, D. Brown, and H. F. Lodish. 1990. Liver glucose transporter: A basolateral protein in hepatocytes and intestine and kidney cells. Am. J. Physiol. 259:C279-C285.
Vandesompele, J., K. De Preter, F. Pattyn, B. Poppe, N. Van Roy A. De Paepe, and F. Speleman. 2002. Accurate normalization of real-time quantitative RT-PCR data by geometric averaging of multiple internal control genes. Genome Biol. 3:RESEARCH0034.

Xu, S., Y. H. Chen, Z. X. Tan, D. D. Xie, C. Zhang, Z. H. Zhang, H. Wang, H. Zhao, D. X. Yu, and D. X. Xu. 2015. Vitamin D3 pretreatment regulates renal inflammatory responses during lipopolysaccharide-induced acute kidney injury. Sci. Rep. 5:18687.

Yabe, D., M. S. Brown, and J. L. Goldstein. 2002. Insig-2, a second endoplasmic reticulum protein that binds SCAP and blocks export of sterol regulatory element-binding proteins. Proc. Natl. Acad. Sci. USA 99:12753-12758.

Yang, T., P. J. Espenshade, M. E. Wright, D. Yabe, Y. Gong, R. Aebersold, J. L. Goldstein, and M. S. Brown. 2002. Crucial step in cholesterol homeostasis: Sterols promote binding of SCAP to INSIG-1, a membrane protein that facilitates retention of SREBPs in ER. Cell 110:489-500.

Yoshida, I., A. Monji, K. Tashiro, K. Nakamura, R. Inoue, and S. Kanba. 2006. Depletion of intracellular Ca2+ store itself may be a major factor in thapsigargin-induced ER stress and apoptosis in PC12 cells. Neurochem. Int. 48:696-702.

Yu, L. C., A. N. Flynn, J. R. Turner, and A. G. Buret. 2005. SGLT1-mediated glucose uptake protects intestinal epithelial cells against LPS-induced apoptosis and barrier defects: A novel cellular rescue mechanism? FASEB J. 19:1822-1835.

Yu, Y., F. J. Pierciey Jr., T. G. Maguire, and J. C. Alwine. 2013 PKR-like endoplasmic reticulum kinase is necessary for lipogenic activation during HCMV infection. PLoS Pathog. 9:e1003266.

Yu, Y., L. Zhang, Q. Liu, L. Tang, H. Sun, and H. Guo. 2015. Endoplasmic reticulum stress preconditioning antagonizes low-density lipoprotein-induced inflammation in human mesangial cells through upregulation of XBP1 and suppression of the IRE1alpha/ IKK/NF-kappaB pathway. Mol. Med. Rep. 11:2048-2054.

Zehnder, D., R. Bland, E. A. Walker, A. R. Bradwell, A. J. Howie, M. Hewison, and P. M. Stewart. 1999. Expression of 25-hydroxyvitamin D3-1alpha-hydroxylase in the human kidney. J. Am. Soc. Nephrol. 10:2465-2473.

Zhou, X., R. Ringseis, G. Wen, and K. Eder. 2015. The pro-inflammatory cytokine tumor necrosis factor $\alpha$ stimulates expression of the carnitine transporter OCTN2 (novel organic cation transporter 2) and carnitine uptake via nuclear factor- $\kappa \mathrm{B}$ in Madin-Darby bovine kidney cells. J. Dairy Sci. 98:3840-3848. 